Portland State University

PDXScholar

\title{
Attitudes of Psychiatric Nurses and Aides at an Oregon State Hospital Toward Homosexuality
}

\author{
Don Andersen \\ Portland State University
}

Follow this and additional works at: https://pdxscholar.library.pdx.edu/open_access_etds

Part of the Community Psychology Commons, Health and Medical Administration Commons, Industrial and Organizational Psychology Commons, and the Occupational and Environmental Health Nursing Commons

Let us know how access to this document benefits you.

\section{Recommended Citation}

Andersen, Don, "Attitudes of Psychiatric Nurses and Aides at an Oregon State Hospital Toward Homosexuality" (1977). Dissertations and Theses. Paper 1992.

https://doi.org/10.15760/etd.1991

This Thesis is brought to you for free and open access. It has been accepted for inclusion in Dissertations and Theses by an authorized administrator of PDXScholar. Please contact us if we can make this document more accessible: pdxscholar@pdx.edu. 
ATITTUDS OF PSYCHTATRTC NURSES AND ATDES AT AN OREGON STATE HOSPITAE TOWARD HOMOSEXUALITY

\author{
by \\ DON ANDERSEN
}

A practicum submitted in partial fulfillment of the requirements for the degree of

MASTER OF SOCTAL WORK

Portland State University

June 1977 
The advisox approved this practicum presented June 5, 1977. 
TABLE OF CONTENTS

LIST OF TABLES $\ldots \ldots \ldots \ldots \ldots \ldots \ldots \ldots \ldots \ldots \ldots \ldots \ldots \ldots \ldots$ CHAPTER

I INTRODUCTION. $\ldots \ldots \ldots \ldots \ldots \ldots \ldots \ldots \ldots \ldots$

II THE GAY LIBERATION MOVEMENT $\ldots \ldots \ldots \ldots \ldots \ldots \ldots .3$

The Scientific Humanitarian Society 1897-1922

England

Other Countries

The Nazis

The Homophile Movement

The U.S.: Early Groups

Gay Liberation

GLF

The Stonewa11 Riots

GAA

Factions

Liberals

Radicals

Socialist Countries

Footnotes for Chapter II

III HOMOSEXUALITY AND MENTAL HEALTH $\ldots \ldots \ldots \ldots \ldots 2$.

Religion

Greece

The Hebrews

The Christians

The Middle Ages

The Inquisition

The Reformation

Science

Freud

Freud's Followers

Other Sciences

Kinsey

Treatment

Recent Theory

Criticism

The American Psychiatric Association

Footnotes for Chapter III 


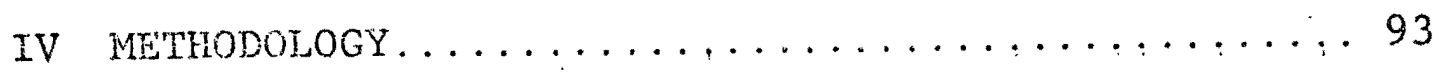

Purpose

The Questionnaire

Data Aralysis

The Pre-Test

Sample and Return Rate

Expectations

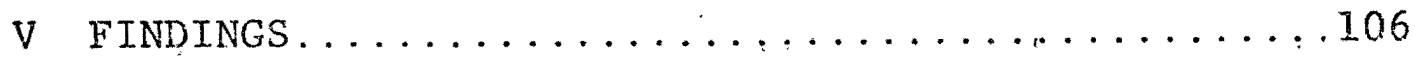

Personal Characteristics of the Sample

and Attitudes

Age

Marital Status

Education

Sex

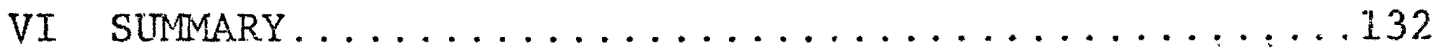

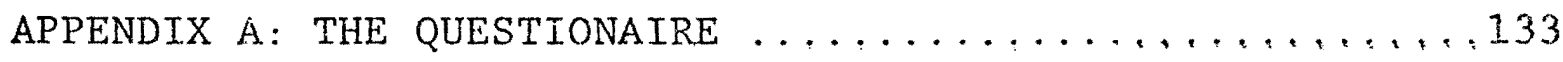

APPENDIX B: EXPLANATION SHEET ........................ 


\section{LIST OF TABLES}

TABLES

PAGE

I Characteristics of the Sample.............

II Response Rate to Radical Statements......... 107

III Response Rates to Liberal Statements.......... 111

VI Response Rates to Conservative Statements ...... 112

$\mathrm{V}$ Age and Radical Statements ............. 113

VI Age and Liberal Statements ............. 115

VII Age and Conservative Statements ........... 117

VIII Marital Status and Radical Statements ......... 119

IX Marital Status and Liberal Statements........, 121

$\mathrm{X}$ Marital Status and Conservative Statements,..... 122

XI Education and Radical Statements .......... 124

XII Education and Liberal Statements .......... 125

XIII Education and Conservative Statements ........ 126

XIV Sex and Radical Statements .............. 128

XV Sex and Liberal Statements .............. 129

XVI Sex and Conservative Statements .......... 130 


\section{CHAPTER I}

\section{INTRODUCTION}

Homosexuality is something which has been a part of almost every society throughout history. In western society this has been a subject of secrecy and taboo. Throughout our history homosexuals have been persecuted and forced to hide their sextal identity. The effects of this on an individual should be something of concern to professionals in the mental health field.

While in the past there has been little knowledge of homosexuality, and no self-expression on the part of homosexuals, there has, in recent years, been growing information and expression. The effect of this change on mental health workers is what this paper will examine.

An historical survey will present the forces which shaped the current attitude of the mental health profession about homosexualjty. I will present a general examination of the social ideology toward homosexuality in western society. I will also review the history of those homosexuals who have banded together for companionship, reform, and protest.

This will be a context against which I will examine the attitudes of a specific group of people who care for the mentally il1--nurses and ailes at a state mental hospital. The questionaire I used to examine their attitudes surveys a broad range of 
possible attitudes about homosexuality. The responses will demonstrate what changes have occurred in society's attitudes toward homosexuality. It will show, specifically, what the attitudes are of those who care for economically disadvantaged, severely distrubed homosexuals. 


\title{
CHAPTER II
}

\section{THE GAY LIBERATION MOVEMENT}

\begin{abstract}
1. The Early Homosexual Rights Movement ${ }^{1}$ The Scientific Humanitarian Committee: $1897-1922$
\end{abstract}

In 1897 the first gay civil liberties organization was formed in Germany. It was called the Scientific Humanitarian Conmittee. They published a yearbook between 1899 and 1923. It was named "Yearbook for Intermediate Sexual Types", and contained reports of the committe's activities; literary, historicai, anthropoligical, polemical, and scientific studies on the subject of homosexuality, and other sex-related phenomenon, stuch as transvestism (wearing the attire of the opposite sex).

The social-political nature of the organization was apprent from its published goals: (1) to win legislative bodies to the position of abolishing the anti-gay paragraph of the German penal code (paragraph 175), (2) enlightening public opinion on homosexuality, (3) interesting the homosexual himself in the struggle for his rights. ${ }^{2}$

The activities of the committee anticipates some of the actions of the modern movement. It held public forums on homosexuality, ard sent out representatives on speaking engagements. It sent copies of its publications and other literature to goverrmental commissions studying revision of penal codes (Russia and Switzerland), and to public libraries. For more 
than two decades it waged a petition campaign agairst paragraph 175 .

Another phenomenon which anticipated more recent events was the collaboration between the committee and women's rights groups .

In late 1910 a new äraft penal code was introduced that proposed to extend criminal status to include sexual acts between women. In response to this, meetings were held throughout Germany to discuss ways to fight the proposed extension, and to link the struggle of women with that of gays.

A new penal code in 1919 dropped any criminal status for lesbians, but provided up to five years imprisonment for male homosexuals. There was, however, a more liberal climate following the war. The committee met with increasing success.

On March 18, 1922 the petition was finally presented to the Reichstag, 25 years after it had been initiated. It was not immediately acted upon however. In the interim the deteriorating economic and social conditions in Germany forced the demise of the Scientific Humanitarian Committee on the eve of success.

Although it failed in its primary goal of getting the anti-homosexual legislation repealed, the committee succeeded in bringing the subject of homosexuality out in the open for the first tine. During its existence thousands of homosexwals were involved in the organization.

England

While this German group was the most successful of the 
period, there was support in other European countires. In England Havelock Ellis and Edward Carpenter founded the British Society for the Study of Sex Psychology in 1914. This group engaged in educational activities designed to persuade the public that since homosexuals had no choice in the matter, they should not be punished for their sexual orientation. The climate in England during the Teens and Twenties was more conservative than Germany. The group did not attempt to organize for repeal of the anti-gay laws.

\section{Other Countries}

In the United States there was little organized activity among homosexuals during this period. A few short-lived groups were formed (such as the Society for Human Rights founded in Chicago in 1925), but their effect was minimal.

With the demise of the Scientific Humanitarian Committee in 1923, homosexual activities in Europe confined themselves to attempts to form congresses of the World League for Sexual Reform in 1928, 1929 and 1930. The only countries which had abolished their anti-homosexual legislation were Denmark, Turkey, and Russia. These had not been the result of organized gay groups. In Russia, the Czarist Anti-homosexual law was abolished by decree in December 1917. It was reinstated by Stalin in 1933 .

The Nazis

In May of that year Nazi storm troopers invaded the Institute for Sexual Science (a research institution founded by the Conmittee in 1919). They burned the publications of the 
Comnittee, of the World League of Sexual Reform, as well as the results of hundreds of studies on sexuality, and literary work. More than 10,000 volumes from the institute were burned.

From 1933 to 1935 the gay movement was exterminated by both the Fascists and the Stalinists.

The Nazis methods at first included sadistic, super masculine-identified homosexuals in its secret army organization, the S.A. Once in power the Nazis excuted Ernst Rohm, the leader, and other homosexuals in the organization. This purge occurred between June 29 and July 1, 1934. This began the terror against homosexuals. Tens of thousands of homosexuals were sent to concentration camps. They were identified in the camps by a pink triangle on their clothing. Hundreds of thousands of homosexuals died under the Nazi regime. ${ }^{3}$

The United States: Early Groups; The Homophile Movement

The repression in Europe, the legacy of inactivity in the United States, and the Second World War kept homosexuals from organizing during the $1930^{\prime} \mathrm{s}$ and $40^{\prime} \mathrm{s}$. The post-war period saw the beginning of the first successful homosexual groups in the United States. The Quaker Emergency Committee was formed in 1945 in New York. It attempted to help homosexuals in trouble with the police. Although it didn't last long, some of its members later formed the George W. Henry Foundation. Also in 1945, the Veteran's Benevolent Association was formed in New York. This group, which lasted about nine years, had primarily recreationa1. goals. 
The Knights of the clock was founded in Los Angeles in 1949. Interracial in character (its founder was a black man), it emphasized social services for homosexuals. It lasted until 1954.

Communication between groups was non-existent, so that these organizations didn't know of each other's existence even in the same city. While the "Knights" was happening, a group of five gay men met in 1950 and formed the Mattachine Foundation. 4 By 1952 there were 18 Mattachine chapters in Los Angeles with thousands of members. They coined the word "Homophile" to describe themselves, since to be homosexual was against the law.

Hollywood was the sight of the House Unamerican Conmittee investigation of Communism in the late 1940's and early 1950's. Accusations of homosexuality were often leveled in attempted character assassinations of those engaged in "unamerican activities".

The Mattachine Foundation was beset by accusations, rumors, and demands for loyalty oaths. At Mattachine Conventions held in April and May, 1953 one member threatened to take the names of all those present to the FBI unless the other members agreed to his requirements for screening new members. The entire directorate resigned as a result of this. A new, smaller organization called the Mattachine Society was formed with new officers and new by-laws. This organization has existed until the present time.

Another lasting group, Onc Inc, was founded as an offshoot of the Mattachine Foundation, on October 15, 1952. ${ }^{5}$ This group's program is primarily educational, with a secondary social service 
function. Their series of lecture programs culminated in the formation of the One Institute in 1960. Through this they offered courses on homosexuality. A monthly magazine called One has been published since 1953. The organization has aided social scientific research, and has a library on homosexuality. For over twenty years One has offered a counseling drop-in service, which has aided some 10,000 people. They now have branches in several cities.

Although these organizations were formed by men, and men remained in the leadership, they all had female members. There were also specifically female groups.

During the 1940's a lesbian friendship circle formed to distribute copies of the publication, Vice Versa, in Los Angeles. These women later provided early editors and staff memebrs for One magazine.

The major organization of women during this period was The Daughters of Bilitis, founded in San Francisco in 1955. This group, which exists to the present time, was until the feminist movement of the late 1960 's, the only organized group of lesbians. 6

Gay Liberation: The Stonewall Riots

The origin of the modern gay liberation movement was clearly the riots which occurred when the New York police raided the Stonewall Inn, a gay bar, in June of $1969 .^{7}$ The fundamental change in viewpoint of the organization formed after this incident, from those already in existence, can be seen in the aspect which makes this incident so significant. For the first time homosexuals 
fought the forces of society. The raiding of gay bars over alleged infringement of the liquor laws is a common occurrence in most cities. Not only did the patrons (mostly transvestites of lower class origin) fight the police, but they shouted slogans of gay ${ }^{8}$ pride and defiance. Some of these slogans were to be taken up by later groups.

The attitude of the previous organizations had been one of acceptance of societal standards. At most they were concerned with the anti-homosexual bias of society.

The groups after Stonewall asserted that "gay is good", and demanded that society change rather than the homosexual. For three nights gays demonstrated in the Greenwich Village area. Police were pelted with rocks. Property was damaged. The demonstrators were beaten and arrested.

Probably much of the new attitude on the part of gays had to do with the other social movements of the time. The 1960's saw many demonstrations and riots. The increasing militancy of the Black movement from its more moderate civil rights beginnings now found its parallel in the emerging gay movement.

The Black movement also provided impetus to the Women's Liberation Movement, the most immediate antecedent of the gay movement. Angry at the male hegemony of the anti-war movement, women began to call into question the male values of society. This provided a basis for effeminate males and strong women to challenge the heterosexual assumptions of society.

Gay Liberation Front

Within a month after the Stonewall riots, the Gay Liberation 
Front was formed in New York. After this, groups sprung up in major cities, and in universities across the country. The GLF based its name on the NLF of Vietnam. This group was the seed of the more militant side of gay liberation.

Gay Activist Alliance

New impetus was also given to the more moderate struggle for gay civil rights. The Gay Activist Alliance was formed in New York to work against anti-gay 1aws. Numerous gay student associations began demanding gay curriculum, as well as providing meeting places and discussion groups.

Many of the early actions were in response to police harrassment of gay bars. While many groups criticized these bars as being economically exploitive and perpetuating an anti-homosexual stigma, it is recognized as one of the few places where gays can meet without being secretive about their sexuality.

The various factions among the modern movement have been able to come together at yearly mass rallies, commemorating the Stonewall riots. The first march drew 10,000 people. Subsequent ones have been even larger. ${ }^{9}$

\section{Factions}

Like other movements, the gay liberation movement has had internal problems and splits. By the Spring of 1970, many of the women in GLF formed a separate caucus to deal with the male dominance of the organization. This evolved into a separate group called the Radicalesbians. They were eventually joined by women from the women's movement who had not previously been 
involved in gay issues. Many smal.1 groups of lesbians have formed, leaving the gyoups addressing so called gay issues only, primarily to gay males.

Recently gay groups have been critized for having memberships which are predominantly white males from middle class backgrounds. Some groups have attempted to respond to this charge by broadening their awareness of lower class and minority gay people. Minority and working class gay people have formed separate causes to raise issues important to them and educate their own communities.

As early as 1970 transvestites formed Street Transvestite Action Revolutionaries (STAR) to meet their special needs. Recently, in San Francisco, latino gays have formed the Gay Latino Alliance (GALA), and a working class caucus of the Bay Area Gay Liberation (BAGL) was started. These groups press for an inclusion. of working class and minority perspectives in the critique of society.

Since the modern gay liberation movement was influenced by the women's liberation movement, there has been an emphasis from the beginning, on personal politics and breaking down barriers between people. A constant theme has been dealing with attractions based on age and beauty. These standards are seen as being divisive and self-destructive. They are attacked as an internationalization of values in heterosexual. society which are unfair and stifling. This trend, however, has been dealt with on a personal level and has not resulted in mass movements or ideological changes.

The basic split between reformist and radical elements in 
the modern gay movement has continued and is deepening. Organizations interested in service to gays have, to some extent, become legitimate institutions in many areas. Many gay people have lobbied for civil rights for many years. This, too, has gained some legitimacy, although changes in the law have been slow in coming.

Liberals

Examples of service organizations include VD clinics, peer counselling centers, referral services for jobs, housing, medical, and temporary shelter. There are drop-in centers and referrals to gay entertainment. Community service centers have existed for years in Los Angeles, Seattle, and other large cities. Also numerous small organizations render these kinds of services.

In many states groups and ad hoc committees pressure socities and institutions for better treatment of homosexuals. They lobby in the legislature. They conduct educational activities, such as distributing films, sending speakers to schools and organizations, and pressuring the media to present accurate representations of gay people. The Portland Town Council, the Society for Individual Rights, the Dorian Society, and the National Gay Task Force are examples of such groups. Currently there is a Task Force on Sexual Preference in Oregon, which is preparing a report to the Governor on gay needs in the state. While acceptance is not widespread, in certain sectors there is support. Some politicians have supported gay issues, and the media is presenting a more favorable picture of homosexuals. 
Another institution in which gays are seeking acceptance is religion. Numerous gay religions have been started, and movements in established religions are growing. This is another area where there is much opposition, but the gay groups are gaining legitimacy. These religions focus theix attention on anti-homosexual passages in the Bible, and finding a basis in religion for a feeling of self-worth. These religions groups include a gay movement within Catholicism called Dignity. There are many local churches in various cities. The largest religious establishment for gays is the Metropolitan Community Church. Started in Los Angeles by the Rev. Troy Perry, this church has thousands of members and branches in several cities.

Many businesses for homosexuals have developed in the past few years. Novelty shops, hair cutting shops, clothes stores, restaurants, and book stores (such as Oscar Wildes in New York) have taken their places amongst the bars and baths in gay neighborhoods. New York and San Francisco have large "gay ghettos" with many such businesses. In other cities they are more scattered and less numerous. The gay press has blossomed, also, since Stonewall. The numerous newspapers vary in viewpoint. Examples of newspapers are the Advocate, Gay Sunshine, Fag Rag, Northwest Gay Review, the Body Politic, RFD (for rural gays), and others.

With a few exceptions this trend in the gay movement carries on the philosophy of the pre-Stonewall organizations. Although more successful, and with a greater sense of self-worth, they, too, want to establish a gay niche in the dominant society. 
Their orientation is middle class, and they model the lifestyle of heterosexuals, including the acceptance of institutions and businesses, and the legal system. They have been successful and endure. There continues to be a rift with those in the gay movement who question the basis of our society.

\section{$\underline{\text { Radicals }}$}

The radicals came to gay liberation from many sources. Some had been in the heterosexual anti-war and civil rights movements. Others first got involved in the Mens Movement (in support of Women's Liberation). Still others came dixectly to gay liberation.

People with a radical viewpoint have been an element in larger groups. There was a basis from the start among people who maintained a new left outlook. They influenced some others within the larger groups. Some men influenced by women's liberation developed a radical outlook in response to the radical element in that movement. Still others in gay liberation became radicalized in response to the criticisms of minorities and lower class gays. Tensions existed from the start within the gay liberation groups. Although the radicals participated in the civil rights activities of the groups this was not their primary emphasis. They pushed for a critique of the heterosexual bas is of societal institutions. Strategic differences emerged as they formed study groups around socialist and Marxist writing. They brought up questions of the oppression of women and the examination of sex roles within gay culture. They became increasingly 
anti-capitalist and wanted an examination of imperialism and the treatment of minorities and workers. Resistance to these demands has led to a turning away from the gay liberation groups and the development of specifically radical gay groups.

Although this has increased recently, there is some precedent almost from the beginning of gay liberation. Since 1969 gay people have gone to Cuba to help harvest sugar cane in the Venceremos Brigade. A gay group calling themselves international Socialists began studying and writing about the works of Engels in London, in 1971. That same year a group called the Freedom Socialist Party formed in Seattle to discuss working class issues. In 1973 a gay group formed in New York called the Youth Against War and Fascism.

The recent acceleration of this trend has spawned several West Coast groups. Lavender and Red Union, formed in Los Angeles, began by attempting to organize the gay community against gay capitalism. Recently they have emphasized the study of Marxism, and the formation of a communist party. Other groups include the June 28th Union, Bay Area Gay Liberation, which is reforming along radical lines, and the Brother Collective. These groups have spent some energy criticizing the anti-homosexual bias in the heterosexual leftist groups. They continue to do this, since some groups have a viewpoint that homosexuality is a product of capitalism.

The specific leftist orientation of gay groups has three general expressions. One is Socialist-Feminism, which places sexism and male dominance alongside economic explotation, as the 
primary enemy. Those which see the Marxist view of the explotation of the working class as the main problem mirror the split in heterosexual Marxism. That is, the Marxist-Leninists (some of whom are pro-Stalin) versus the Trotskyists; the antihomosexual bias which all these groups face from the left also exists on an international scale. Since the radicals see their concerns as part of worldwide anti-capitalist issues, the treatment of homosexuals in socialist countries is an important issue to them.

Socialist Countires

None of the modern nations afford homosexuality a place equal to heterosexuality in their societies. There has been much interest on the part of the Marxists in the gay movement, about the status of gays in the countries which have changed to a socialist economic system.

Until recent years China was closed to the West and information was scarce. Although there is information on the position of women, there is nothing in the literature on the position of homosexuals. Recent visitors concerned with this question give the impression that, although there are homosexuals in China, the official position is that it dosen't exist. This is not surprising, given the puritanical attitude about sexuality in general, within Chinese society.

Information is lacking also regarding homosexuality in Russian society. It is safe to assume that the official attitude has not changed since Stalin reintroduced the sodomy law. Since Khruschev's time Soviet society has become more Westernized, and 
probably has similar policies on homosexuality, as the western European countires.

Cuba is the only socialist country which has had its position on homosexuality discussed in the literature of the American Gay left. This is the result of the exposure of American leftists to Cuban society, starting in the late 1960's. The emergence of the modern Gay Liberation movement at about the same time prompted an interest in Cuba's treatment of homosexuals. Most of the articles are personal accounts by gays who have gone to Cuba to study or work. The majority of these people have found Cuban policy repressive.

Anti-homosexuality in Cuban culture has its roots in the influence of the Catholic Church, and the strict sex roles of Latin society. In pre-revolution Cuba, homosexuality was illegal and carried severe penalties. Homosexuality existed in the large cities, along with female prostitution, drugs, and gambling; it was controlled by the Mafia for the benfit of American tourism. For this reason Castro's revolutionaries saw homosexuality as an example of the decadence brought on by imperialist rule. Although Cuba's homosexuals welcomed the revolutionaries as a force which would liberate them, the new government set about eliminating homosexuality.

The accounts by American radicals indicate that in $1965^{10}$ thousands of gays were sent to the Military Units to increase production (UMAP). This seems to have been a euphemism for forced labor camps. The officials who discussed this felt that this approach had been a mistake. The camps were phased out after a 
short time, but life for homosexuals was not easy. There were few places for gay people to meet, the newspapers presented anti-homosexual articles and cartoons. The official attitude was that it was unnatural.

As mentioned before, radical leftists who were gay were hidden until the formation of the Gay Liberation Movement in 1969. Many of these people, with a new consciousness about homosexuality, were to participate in the Venceremos Brigades. These were brigades of Americans who went to Cuba to harvest sugar cane. Starting in 1969, the harvesting of cane was intensified to bolster the Cuban economy. The gay workers came back with reports of abuse because of their homosexuality. The workers on the brigade formed caucuses along racial and class lines. When a gay caucus was formed, they were forbidden to meet. There were also beatings and verbal abuse. 11

The criticism of Cuban machismo and anti-homosexuality has been attacked by some of the heterosexual left in this country, and by official Cuba. They make these requirements; change in Cuban saciety will take time. Americans should not attempt to foist their values on Cuban society. Because Cuba is an anticapitalist society, in a vulnerable position, American Marists should support it, and not critize it.

In 1971, Cuba held a Congress on Education and Culture, which critized homosexuality. Their declaration called homosexuality a "deviation", a "social pathology". They recommended keeping gays out of the Arts and Education, and the provision of sex education with a heterosexual emphasis, in the schools. 
The theory behind this was that, contrary to the evidence of history, homosexuality could be totally eliminated by keeping gays away from children, and by avojding sexual confusion through educating youth. 12

The method of dealing with prominent homosexuals is to isolate them in jobs where they won't contact the public. While there are no sodomy laws, less prominent gays are restricted from being open in public, by the public scandal law. With this and the chronic shortage of housing, where gays might find privacy, there is Iittle opportunity for homosexual expression in Cuba. 
FOOTNOTES FOR CHAPTER II

${ }^{1}$ John Lauritsen and David Thorstad, The Early Homosexual Rights Movement (New York: Times Change Press, 1974). This book is a major source of homosexual rights activity from 1864 to 1935 .

2 Ibid., p. 11.

3 kichard Plant, "The Men with the Pink Triangle". Christopher Street I:8 (February, 1977), p. 4. This is an account by a homosexual who escaped Nazi Germany. He describes the Roehrn affair: "At the start of Hitler's career he met Ernst Roehm, a short, plump, scarred mercenary, deliberately vulgar, a "butch" lover of handsome boys .... Roehm built up Hitler's first squadrons, the S.A., from a tiny collection of dropouts ... into a tough paramilitary troop, numbering one hundred thousand by 1931." He was becoming so powerful that he threatened the other leaders. He also demanded that th S.A. be made part of the Army. "Hitler needed the Reichswehr to stay in power .... though many of the .... generals loathed him, they loathed Roenm even more. The leaders of big industry whom Hitler was courting for funds also despised Roehm." S.S. leader Himmler urged Hitler to get rid of Roehm. In June, 1934 S.S. troops were sent to kilI the leaders of the S.A., who were on vacation. They were killed and Roehm was jailed. He refused the chance to kill himself, and was shot a few days later.

Himmler drafted an "enemies 1ist". S.A. and others were rounded up in the inajor cities. "The infamous "Iight of the Long Knives" had staried. On June 28, 1935, over two thous and people were eliminated." To justify this purge, "Goebbels stressed the "homosexual horrors". Quickly the famous Paragraph 175 was changed to $175 \mathrm{~A} \ldots$ now any contact between males of any age that could be construed as sexual. would be severely punished ... This new law was made public on June 28,1935 , as a directive for "the ruthless persecution of sexual vagrants", and the date referred directly to Ernest Roehm."

"In October, 1936, Himmler demanded the "elimination of al1 degenerates" ... by November, 1941, Hinmler ... proposed castration for minor offenses, death for major ones." Plant goes on to describe the horrors of the concentration camps for gays.

${ }^{4}$ Dermi is Altman, "Homosexual: Oppression and Liberation

(New York: Avon, 1971), p. 114

${ }^{5}$ Ibid., p. 11.5 
${ }^{6}$ Ibid.

7 Fran Winant, "Christopher Street Liberation Day", in Out of the Closets: Voices of Gay Liberation, ed. Karla Jay and Allen Young (New York: Douglas, 1972), p. 4.

8 Ibjd.

${ }^{9}$ Ibid., p. 26

10 Ibid.

${ }^{11}$ Patrick Haggerty, "Out, Out, Damn Faggot", in The Gay Liberation Book, ed. Len Richmond and Gary Noguera (San Francisco: Ramparts Press, 1973), p. 69

12"Declaration by the First National Congress on Education and Culture", in Out of the Closets (Op. cit., ref. 7), p. 246. 
CHAPTER III

HOMOSEXUALITY AND MENTAL HEALTH

I. INTRODUCTION

This chapter will present an historical survey of the ideology regarding homosexuality of those institutions, which have controlled western society. I will focus upon the most recent of these, the mental health institution, as a preparation for the survey of mental health worker attitudes.

In surveying the literature, I find that, historically, three institutions have been successively superimposed upon one another as authority structures in society. First, it was the religious system, then the legal system, then the mental health system. These have been the instruments of sanction and control of society's superstructure.

i'hroughout most of our history, these have engaged in stringent efforts to suppress and eliminate homosexuality. It is only in the earliest period, and possibly in the most recent, that homosexuality has been given some measure of validity. Religion

Homosexuality has been a human phenomenon since before recorded history. Although societies have responded in various ways at any given historical period, it is possible to talk about three eras in Western civilization. Homosexuality has been under first the religious authority, then civil authority, and finally 
the psychiatxic establishment.

Religion was the primary unifying institution of prehistorical and early historical civilizations. The earliest evidence of human societies from the Near East indicate the primacy of religions centered around a Great Mother Goddess. ${ }^{13}$ As we get closer to historical times we find these religions beconing solidified and ritualized. The goddess was known as Artemis in Ephesus, Aphrodite in Corinth, Astarte in Phoenicia, Ishtar in Babylon, Isis in Egypt, Atargatis in Canaan, Anatis in Persia, Rhea in Crete, Cybele in Phrygia, and Bendis in Ihrace. 14 From the accounts of ancient writers, we know that the rites of the goddess included many forms of sexual practices, both heterosexual and homosexual. 15

The female goddess represented life and had androgynous characteristics. She was the unifying principle for all things in life. ${ }^{16}$ Pleasure, in the form of sexuality, was channeled rather than suppressed. There were no forms which were though of as deviant.

The earliest historical societies continued this approach to religion. 17 However, the previous hegemony of the female in religion and civilization was gradually overtaken by patriarchal power. Lineage began to be traced through the father. Males entered the role of religious leaders. The male characteristics of the goddess began to be split off into separate male gods. A dichotomy was set up between male and female principles. ${ }^{18}$ This encouraged a greater separation of behavior, including sexual, between men and women. 
These ancient civilizations represented transitional societies in this process. Same-gender sexuality, anal/ora1 sexuality, auto-eroticism, transvestism, and other forms of sexuality maintained an honored place in the religious structure. Temple prostitutes, both male and female, performed hoinosexual religious rites. Egypt, starting out with a single goddess, developed co-equal male and female deities. ${ }^{19}$. Civic rule was dominated by a brother-and-sister leadership, while men entered the religious sphrere as priests. It represented a compromise point in the historical ascendancy of the patriarchy over the matriarchy. 20

\section{Greece}

In the Greek civilization we find the solidification of male hegemony and the first instance of secularization of government. Homosexuality was preserved and elevated to an honored place in society, but only for men. 21 The devolution of the female was now complete. Male gods were primary, secular rule was in the hands of men exclusively. Greek rulers lived in nuclear families dominated by the father/husband. Heterosexuality was exercised for procreation, while male homosexuality was exalted for its pleasure. 22

The elevated position of the female in the pre-historical religions had come full circle. But the pleasure principle, including non-purposive forms of sexuality, such as male homosexuality, was maintained. The next state of the evolution came about through the Hebrews. 
The Hebrews

The ancient Hebrews, before the Baylonian Exile (circa. 700 BC) had a female-dominated religion, sharing many characteristics of the other early religions, including mouth-genital contact and homosexual activities. 23 Within about a fifty year period, conservative Hebrew factions began to reformulate and insist on an ascetic philosophy. Along with a single male diety, and the concept of themselves as the "chosen" people, sexuality was restricted to a purposive function, in order to unify their people, after a history of many terminal onslaughts. A variety of new condemnations were established by classification. Acts were clean or unclean, and prohibitions were set up against particular animals, foods and most forms of sexual activity. The lowly status of women was further specified through prohibition from religious participation, and banishment during menstruation. 24

The concept of unnaturalness and affrontery to God were introduced as justifications. It was necessary to resort to ultimate injunctions to obliterate widespread practices from the past. Sex was strictly for reproductions; sex for pleasure, including homosexuality, was completely forbidden. This tendency in Jewish law did not become completely pervasive until the punitive, highly restrictive moral arguments put forth in the Talmud, which was written just prior to and during the time of the early Christians. 25

The Christians

Christ represents the unification of the major patriarchal tenets. Here was the embodiment of patrilineage, the human/godly, 
monotheism, and male religion. He was the human God/Son of the single, omipotent God/father. Since the first Christians were Jews living under Roman rule, their ideas derived from a combination of Jewish sex law, and the philosophy of the more ascetic Roman cults.

The Roman culture had replaced the Etruscans, about whom little is known. The early Roman culture was a spartan agricultural society. It was based on patriarchal extended families, in which the posjtion of women was low. These families evolved into a ruling class, and the Romans began conquering neighboring societies. Roman culture was eclectic almost from the beginning. Their religion was based on that of the Greeks, but without the ritualistic emphasis on homosexuality. Sexuality was increasingly a secular matter. As Roman wealth increased, homosexuality became more widespread, along with increasing citizen participation, and a more equal status for women.

As the Empire embraced more foreign peoples, the many goddess-oriented, pan-sexual religions began to have an influence. Rather than being synthesized into the state religion, these uprooted cultures existed simultaneously in a rather chaotic situation which lasted for several centuries. ${ }^{26}$ The official Greek-derived religion held less sway, and competed with many, often opposed, religious ideas.

It was in reaction to this unstable situation that the Roman ascetic cults (derived from those in Greece) formed an influence along with the Essenes (Jewish conservatives) an early Christianity. 27 It was easy to equate the chronically 
unstable social situation with the homosexuality practiced by the goddess-oriented peoples now in the empire.

At first Christianity consisted of several factions, each with a different doctrine on sexuality. Issues such as clerical marriage, castration, mutual-consent marriage, and chastity were given justification in the words of Christ, the Apostles, and the Church fathers. 28

There was little in the words of Jesus about sexuality. One statement, however, proved to be significant in the shift of emphasis from previous Hebrew law: "... whosoever looketh on a woman to lust after her hath committed adultery with her already in his heart". 29 By this statement, Christianity introduced the concept of moral behavior based on one's intentions, rather than outward conformity. They thus made the transition from a religion of shame to a religion of guilt. Pleasure was tied inexorably to sin.

Saint Paul was the greatest influence on what the Christian doctrine was to be. He solidified an extreme anti-pleasure doctrine. All sexual practices, save heterosexual contact with the male on top, and without the intention of enjoyment, were forbidden. Homosexuality was so far from being sanctioned, that it was spoken of only in the most vitriolic terms: "... even their women did change the natural use into that which is against nature ... The men, leaving the natural use of the women, burned in their lust one toward another, filled with all unrighteousness, fornication, wickedness, covetousness, maliciousness; full of envy, murder, debate, conceit, malignity". 30 
This asceticism and self-control had a strong appeal to people experiencing the instability of the floundering Roman Empire. Roman rule entered into partnership with the increasingly strong Church. The Bishop of Rome became the real seat of power in the West. As barbarian states began to be set up in once Roman territory, it was propitious to gain a measure of authority by adopting Christianity. ${ }^{31}$ Thus, the ruling class of Italy and France adopted the new religion, with its new moral code. Eventually, missionaries were sent to the British Isles and Germany, and the new kingdoms there became Christian.

As the influence of the Church became entrenched throughout Europe, the strict doctrine on sexuality was undercut both from within and without. Within the church, the growing body of pronouncements on homosexuality indicated widespread practice on the part of the cleric, particularly within the growing monastic movement. ${ }^{32}$ The most important theologian was Augustine of Hippo. He wrote, "Sins against nature, like the sin of Sodom, are abominable, and deserve punishment wherever and whenever they are committed." 33 The Council of Elvira, in 305, denied communion to homosexuals and prostitutes. In 390, the Emperor Valentinian decreed that homosexuals were to be burned at the stake. ${ }^{34}$ The eastern emperor Justinian codified Roman law in $538 .{ }^{35}$ One section of the Code stated that famine, earthquake, plague, and destruction would befall cities harboring homosexuals. Therefore, they were to be tortured, mutilated, paraded in pubiic, and executed. 36 
The Middle Ages

Although homosexuality and injunctions against it were widespread, and constant, during the Middle Ages, the offenses were committed on an individual basis, and prosecutions were sporadic. ${ }^{37}$ The real threat came from organized religious practices outside the Church. This phenomenon led to the harsher treatment by the Christians later on.

Many of the indigenous people of Europe practiced a goddessoriented, pro-sexual religion. The spread of Christianity was largely at the upper levels of society. The Church often failed to make inroads into the religious practices of the lower classes. The strongest adherents of the goddess religion were the Celts. The Celts migrated across western Europe in pre-Christian times. ${ }^{38}$ Settling primarily in Gual and the British Isles, they continued to practice their rituals, including homosexuality, after Christian states were set up. ${ }^{39}$ Finding it impossible to convert these people, the Church settled for economic and legal control. 40

It wasn't until groups of Christians began to incorporate some of the native rituals that the Church began active opposition. This was seen as heresy, threatening the internal unity of Christianity. From the early days of the Christians, minority opinions were labeled as heresies by the dominant factions at various councils. Originally, most of the heresies involved disputes over doctrinal matters and interpretations of the Bible. The first heresy relating to homosexuality, and the goddess religion, occurred in the Eastern Empire, in a semi-independent state called Bulgaria. The Bulgars were a Turco-Tartar tribe, 
who had migrated from Russia to the Eastern Empire. Byzantium conquered them in the ninth century, and imposes Christianity. A Christian splinter group appeared in the Balkans, called the Massalians. They were opposed to Church bierarchy and Byzantine rule. They also allied with the adherents of the pagan religion. ${ }^{42}$ The Massalians practiced a mixture of asceticism and sensual indulgence. Upon initiation, a member spent a period of time in strict self-denial, after which one was considered purified, and no longer subject to sin. Once purified, they practiced homosexual rituals similar to the pagans. They also had women in leadership roles. 43

In the tenth century another Christian splinter group emerged in Bulgaria, the Bogomils. At first they were a strictly ascetic Christian sect. In time, Church opposition drove the two groups together. By the twelfth century Massalian influence on the Bogomils was strong. They had completely fused by the fourteenth century. The Bogomils increasingly aligned themselves with the pagans against attempts by the military to impose Christianity in Bulgaria. ${ }^{44}$ They were associated in the 1iterature with popular superstition and magic. The word Bogomil also came to be synonymous with homosexual. Their beliefs spread over southern Europe. In the vernacular of various countries the word for Bulgarian came to mean homosexual. (The origin of the English slang for anal-intercourse is "bugger"). 45 They influenced later heresies, such as the Cathari, amongst the Albigensians of southern France. It was these heresies, associated with homosexuality and sexual license, which led to the Inquisition. 40 
The Bogomil influence ended when Bulgaria was conquered by the Turks in 1393. Because of their association with the Bogomils, the Cathari were widely accused of homosexuality. As with the Bogomils, women held important positions in their sect. In 1209, Pope Innocent III launched a crusade against them. He organized the nobles of northern France, and by 1229 they were practically wiped out. 47

The Inquisition

This did not stop the spread of heresies involving homosexuality. Papal legislation was passed during the period, 1227 to 1235 creating a new institution, the Holy Inquisition. ${ }^{48}$ For the next few centuries heresy, homosexuality, and witchcraft were used interchangably to torture and kill millions of people. Two German Dominicians, Sprenger and Kramer, conducted merciless witch hunts, and raised so much popular opposition that they could not continue without papal support. In 1484 they got Pope Innocent VII to issue a bul1, Summa Desiderantes, ${ }^{49}$ which condemned witchcraft. Shortly after this, Sprenger and Kramer wrote Malleus Malleficarum - The Witch's Hammer, a handbook for discovering witches. It went through twenty-eight editions over the next few centuries. Six of the seven chapters dealt with sex. 50

The era of the Catholic hegemony in Europe had been maxked by blatant sexual hypocrisy of the Church leaders, and cruel sexual oppression of outsiders. This produced an increasingly tense situation and one factor leading to the Inquisition was an attempt to snuff out all opposition before it got started. As 
with all history, homosexuals existed, and because they were a minority they made an easy target to paranoia, and increased Church control.

The Church was largely successful in wiping out the last vestiges of pro-sexual religions, but they lost much ground to a new opponent, who was to go them one better in anti-sexuality, the Protestants.

The Reformation

Church and State authority had always been in an uneasy partnership as regulators of society. Increasingly the State gained control, but only after Christian morality had been permanently imbedded into the legal system. The Reformation, especially Puritanism, represented the religious philosophy of the rising middle class. Power to investigate and prosecute passed steadily from ecclesiastic to civil courts. When henry VIII seized authority from the Church in 1533, he made sodomy a civil felony punishable by death. ${ }^{51}$ The Protestantism of England was primarily a secularization of Catholic philosophy.

With Luther, a fundamental change occurred in the handling of sexual desire. On a visit to Rome, Luther was shocked by the sexual indulgence, and open homosexuality, of the Church leaders. He blamed this on the attempt to abstain, which he felt led to sexual deviance. The power of lust was so deep no human could resist. Attempting celibacy was an invitation to the devil. He insisted on family solidarity, wifely submission, the sinfulness and necessity of sex, and the shamefulness of deviance. ${ }^{52}$ Calvin took a similar position, calling marital intercourse "pure, 
honorable, and holy, a veil by which the fault of lust is covered over, so that it no longer appears in the sight of God". 53 Work and heterosexual family life were harshly fostered norms of society. This morality was dominant in the secular state, and spread to the English colonies in the New World. Massachusetts and Plymouth demanded death for murder, witchcraft, sodomy, rape, and bestiality.

The Reformation broke the centralized, temporal power of the Catholic Church, even gradually in those countries remaining Catholic. Anti-homosexuality was still strong, but was now completely a civil matter. The deviancies previously handled by the Church were now the problem of the state. Between 1600 and 1800 the Bicetre in France housed criminals, psychotics, victims of $\mathrm{VD}$, political prisoners, beggars, the aged, and homosexuals. 54 The Bastille also houses homosexuals during the eighteenth century. It wasn't until the latter part of this century that there were more than a few institutions for the mentally disturbed, for the concept of mental illness hardly existed.

Science

Homosexuality continued to be a crime, with harsh penalties. Though capical punishment was abolished for many crimes in England in 1837, it was retained for murder, rape, and homosexuality. 55 European morality had solidified around the institution of the middle class family. In England this was called Victorianism. It arose in a wave of prudery, guilt, and religious reformism in the second half of the eighteenth century. Protestant 
domestication off romantic love became entrenched. There were numerous new reizicus reform movements in reaction to the sensual excesses of upper class life. In 1738, John Wesley started a movement called Methodism, which strongly affected the middle class. The burden for sexual control was now placed on men. Women were desexualized. The ideal of the pure, chaste virgin developed. There was a growing preoccupation with appearances. It was under the sway of these values that scientific thought developed.

Although the scientific study of sex didn't begin until the mid-nineteenth century, there were significant earlier developments. In 1758, Tissot (a Swiss physician) wrote Onania, or a Treatise upon the Disorders Produced by Masturbation. ${ }^{56}$ In America, Benjamin Rush wrote the first text on mental disorders, including masturbation. After Darwin's theory of natural selection appeared, scientists began applying it to social phenomena. The heterosexual family of the middle class Victorian was seen as the highest evolution of the human race. Deviants were seen as adaptive failures sliding backward to destruction amid the ranks of a progressing species. Since their deviancy was thought to be caused by a degeneration of their genes, they were often called degenerates.

In 1835, the English psychologist Pritchard added to the growing study of mental illness by introducing the concept of "moral insanity"---a "morbid perversion" of the feelings and impulses without delusion or loss of intellect. 57

The word "homosexual" did not yet exist. Where it was labeled, rather than simply vilified, it was most often called 
sodomy, or pederasty. With the growing awareness that people with the same gender identification didn't always engage in sodomy or pederasty, there developed a need for a new label. Ulrichs turned to Plato's Symposium for a description of same-genderidentified people who worshipped the goddess Urania. Ulrichs Germanized the word for Uranian, thus called them "urnings". 58 The word homosexual was coined in 1869 by a Hungarian physician named Benkert. He used the Greek work "homos", meaning "same".

The German journal krchiv fur Psychiatrie published increasing numbers of articles on sexual behavior, starting with a study on transvestites by $\mathrm{Dr}$. Karl Westphal. It was more systematic and objective than anything written until then. Westphal calied homosexuality a "contrary sexual feeling". He claimed moral insanity was due to "congenital reversal of sexual feeling". 59

The idea of the homosexual posessing a not fully developed brain was again put forth in 1882, in Inversion of the Genital Sense by Charcot and Magnan. 60 "Invert" was widely used to mean "homosexua1".

The idea of congenital homosexuality was the dominant theory. The scientists arguing this, firmly established the idea of homosexuality as a sickness. While this often led them to advocating the decrininalizing of it, homosexuality now became both a sickness and a crime. Since much of society was influenced by religious morality, it was also still called a sin. The development of Freud's theory of universal human psychic development arose amidst a heritage of thousands of years of anti-homosexuality. 
A new element of the ideology had been developed with the concept of fixated sexual development in homosexuals. Freud inherited this idea from the leading scientist of the time, most directly throuth Charcot. He was to develop this to fruition and give it pervasive authority. Homosexuality was still unnatural, not only because God said so, but now because biology indicated so. The norm of heterosexuality remained unquestioned.

Freud

Freud was born into a middle class Jewish family in Freiberg in 1856. His family moved to Vienna, and he eventually became a doctor there. By the time he was in his late twenties he was already renowned as a diagnostician, researcher in neuro-anatomy, and lecturer on nervous diseases.

One of his acquaintances, Dr. Breur, was treating "Fraulein Anna $0 . "$, who suffered from phobias and hysterical conversion symptoms. Freud joined Breur on the case and saw that under hypnosis she could remember the first occurence of an husterical symptom and the feelings associated with it; when she awoke, bringing the memory into waking life, the symptom was gone. 61

In 1885, Freud went to Paris to see Dr. Charcot. Freud was deeply impressed by Charcot's hypnotic cures. He remembered Charcot's embryonic development theory, and the remark Charcot had made, "In such cases it's always the sexual thing---always, always, always!". 62 From his own cases, Freud began to feel that early sexual trauna was common in hysterics, perhaps almost universal. 
In 1895, Freud and Breur published Studies in Hysteria, 63 which stated that hysterical symptoms could be cured by the recall and catharsis of repressed traumas. The two men split up over Freud's contentions that sexual traumas could predate puberty. It was considered an outrage at the time to say that small children had sexual feelings.

Freud stopped using hypnosis because it always met resistance at some level. Freud also felt the patient must do the work of unearthing the trauma. He had patients say whatever came to their minds, calling this "free association". Since they often spoke of dreams, he also began dream analysis. In 1900, he published The Interpretation of Dreams, ${ }^{64}$ finding much unconscious material in them.

Freud began to think that early sex lives of his cli.ents often involved incenstuous conflicts. Many clients reported incidents of childhood seduction. He began to realize, however, that these stories were often fabrications. He made a reinterpretation of these stories as wishful fantasies. Neuroses represent defenses against these shameful thoughts. He decided that, like Oedipus, every child wants to possess their parent of the opposite sex, and destroy the rival parent of the same sex.

He developed the theory of a sexual instinct called the libido. ${ }^{65}$ He theorized that libido travels in the normal development of a child, from the mouth to the anus, to the genitals. Certain life experiences and feelings coincide with each period of libidinal focus, and are fused with it, determining much in adult sexuality and personality. When left undisturbed, this 
natural process leads to heterosexuality. If an individual fixates on an early stage, neurosis or perversion results.

In the first stage of infancy, libido focuses in the mouth and eroticizes sucking and feeding. The child has no sense of separate existence; pleasure is a passive, self-centered experience. Some libido remains in the mouth, ${ }^{66}$ and there will always be pleasure in eating, kissing, sucking, and biting.

The next stage is precipitated by toilet training. The libido focuses on the anus. Witholding and releasing feces has the pleasurable pattern of tension and relief. The child treasures the warmth and smell of the feces as part of himself. The child can defy the parent by holding or letting go at the wrong time. Finally, they learn to please the parent; narcissistic body-love is repressed for the sake of others. The first reaction-formation is created; learning to be disgusted by the feces.

Next, libido moves to the genitals. At first, this is self-centered, but becomes other-oriented. It is here that Oedipal conflict occurs, for the child's first object of attraction is the parent of the opposite sex. The child fears punishment from the parent of the same sex. Thus the child fears castration. (Freud developed the theory on the model of the boy. He later said that the girl feels she already has been castrated, and therefore feels "penis envy").

In talking about homosexuality, Freud theorized that homosexuals are people who became fixated at the anal stage, with ideas and feeling of this stage dominating the personality. 67 The person may be openly anal-erotic, or may develop defenses 
against the shameful anality. In the latter case, the person is rigid, neat, controlled, and stubborn, controlling and denying the child within, who wants to release their feces and play in it. Since the duality of compliance and defiance is fought by the child during the anal stage, sado-masochism will be a part of the anal personality. A pervert, deprived of their perversion, will be a neurotic. Similarly, a neurotic is fleeing a repressed perversion.

Two childhood events can predestine one for homosexuality; the "inverted" Oedipal complex, and narcissism. During the Oedipal phase, a boy may resent his mother for preferring the father, and reject her. Because of his bisexual nature, he has feminine urges for the father, and is jealous of the mother. If he is more feminine and passive than normal, the Oedipal crush may remain inverted and he will remain a homosexual.

There were within Freudian theory two features which might have validated homosexuality. He assumed and gave further evidence to the idea that we start life basically bisexual, and that sexual preference is conditioned by society through the parents. Freud also maintained that there is no sharp delineation between the sane and the insane, or perverted. The same sort of unconscious and the same mechanisms for controlling it exist in everyone. The abnormal express in exaggerated form what every child feels, and what continues to exist in the child in everyone,

Freud made many contradictory statements and revisions during his career. He made some statements to the effect that 
homosexuality was not exactly a mental illness. In his Three Essays on the Theory of Sexuality, 68 he said, "Inversion is found in people who exhibit no other serious deviations from the normal. It is similarly found in people whose efficiency is unimpaired and who are indeed distinguished by specially high intellectual development and ethical culture". 69 This distinction is not a validation, however. He clearly assumes that the abnormality is homosexuality. Once again in "Letter to the Mother of an American Homosexual", he establishes the notion of deviance: "Hornosexuality is assuredly no advantage, but it is nothing to be ashamed of, no vice, no degradation, it cannot be classified as an illness; we consider it to be a variation of sexual functions produced by a certain arrest of sexual development". 70

Because Freud was the product of a culture of thousands of years of anti-homosexuality and the dominance of the male heterosexual, there is an implicit homosexual inferiority at the base of his theory.

Instinct theory, then, dominated medical and biological research, 71 and the new science of genetics provided an explanation for the transmission of instinct. The sequence of psychosexual development, Freud though, must be set hereditarily, and the individual driven to follow it by instinct. He posited a kind of primal determinism. Kissing reflects breast feeding; neatness develops out of toilet training; miserliness, from the attempt to hold on to one's feces; ambition, as a reflection of penis power. 
Sexual development went through pre-ordained stages, with a procreative aim. Non-procreative sex was "infantile". The child's sexuality was "polymorphous perverse". (Ironically, perversion was more fundamental than "normal sexuality").

At the time his theory was developed, there was little knowlege of the extent or varieties of homosexuality. Little was known of learning processes and cross-cultural data. The assumptions of western society were seen as absolute. Civilization, meaning Freud's society, demanded repression and heterosexuality. This was what was normal.

Although Freud made changes, his theory was basically developed early on. He set a precedent for the later treatment of homosexuals by developing a complete theory of human psychological development based on data gathered from people who were disturbed. The extend to which his theory became rigid can be seen in the development of his work with clients. He embarked on his career by working with "Fraulein Anna O." who displayed serious hysteric symptoms. All his patients during the development of his theory displayed similar extreme symptoms. By 1920, Freud was unable to validate a person who displayed no symptoms of disturbance.

In that year, he published the report of an eighteen-year old lesbian. She was sent to him by her parents. She agreed to see him to please her parents, particularly her father, who was greatly upset by her attraction to an older woman. She herself felt no need to give up her homosexuality. Freud proceeded to analyze her from his theory of childhood development.

He reported that during her Dedipal period, she felt 
betrayed by her father because he preferred her mother. She therefore held back the "flowering of her femininity". 72 At puberty this conflict was revived. He mother became pregnant at that time and she utterly renounced her femininity. She was using her lesbianism to repay her parents for their betrayal. Freud put no credence in the fact that she was content to be a lesbian. He was offended that she was not impressed with his analysis of her. "She seriously considred all explanations offered her as though she were a 'grande dame' being taken over as a museum piece, and glancing through her lorgnon at objects to which she was completely indifferent". ${ }^{73}$ Freud's interpretation makes sense only if one comes to it thinking that homosexuality is unnatural. He attempted to prove this unnaturalness from his earlier work with people who were disturbed. 74

Freud's theory provided an ideal means of continuing the basic values of society by giving them a (inistorically necessary) shift in justification. Scientific method was making significant inroads into the mystical beliefs fostered by religion. The physical sciences unearthed patterns in nature and demonstrated a significant degree of predictability. Science was demonstrating an accountability which religion had assumed could not exist. Proof replaced faith. If morality, which the rulers of western society found necessary, was to be maintained, it would have to be based on more than absolute pronouncements.

Freudian theory, like western religion, found homosexuality unnatural, saw the heterosexual family as the standard for judging human behavior, and based interpretations of the female on a 
basic male model. Freudianism, however, made claims to be an objective science. Like the physical sciences, it labeled a biological pattern of development. Although it had some logical validity within its own system, it could not be tested as the physical sciences were. Feelings and experiences could not be isolated and examined as matter could be. No significant universe could be gathered and studied, and few predictable cures could be claimed by psychoanalysis, as compared to medicine. At a time when religious authority was fading, psychoanalysis provided a pseudo-scientific basis for the same morality.

Freudian theory left much for later followers and critics to discuss. Just as Freud's theory was less mystical than religious dogma, so his followers developed theories which abandoned some of the more mystical elements of his. In general, those who came later tended to replace instinct theory with more observable explanations. In the competition between interpretations, those which more coincided with and supported dominant social values, tended to predominate. The followers of Freud continued to generalize from the disturbed. In the process of being more down-to-earth, they created a series of stereotypes about the development of homosexuality, while stimultaneously asserting a rather narrow standard of gender-linked behavior.

Freud's Followers

In 1902, Freud contacted Alfred Adler and Wilhelm Stekel. This was the nucleus of the Vienna Psychoanalytic Society. They were joined by June, Bleuler, Sadger, Ferenczi, Abraham, Brill and others who were to develop and popularize psychoanalytic 
theory. By 1911 Alfred Adler found himself so intellectually at odds with Freud that he became the first major apostate of the psychoanalytic movement.

Adler, rejectrof the idea"the libido, or any "instinct", is the force behind neurosis. He developed a theory of deviance and homosexuality which emphasized the need to master one's environment, and personal fate. A person's first experience of life is being sma11, weak, and helpless. The ways the child is fed, handled, and spoken to influence feelings of security, timidity or defiance. The person continues these traits into later life. ${ }^{75}$

In a crucial development of his theory, Adler correctly defined societal expectations, without challenging them. He explained that the child learns that society equates masculinity with courage, freedom, the right and ability to assert will and aggression. It equates femininity with obedience, dependence, and inhibition. If the child fails to achieve the qualities of its gender, a sense of discomfort results. Feelings of inferiority predispose one to neurosis. Once again speaking from a male model, he said the child must protect his masculinity (superiority); to do so he denies his weakness (femininity) and overcompensates for it. He said, "The Jerusalem of every neurosis is, "I want to be a real man". 76

Adler's difference from Freud was the shift in emphasis from biological to social forces. Because, like Freud, he failed to see the transient, arbitrary nature of social values (and the factional bias), he went farther in creating a theory of homosexual abnormaiity. His recognition of social pressure, while 
correct, sacrificed individual self-definition to the norms of the particular society. As we have seen, homosexuality became socially deviant through a specific process and for specific reasons.

Confusing cause and effect, he viewed homosexuality as one of many types of failure to cope with life, with a "heterosexual world". As a lifestyle it reflected low self-esteem. He paved the way for later treatments by disputing the innateness which led Freud to be pessimistic about the possibility of changing homosexuals into heterosexuals. "There can be no sexual perversion without training".7.7 Treatment, therefore, consists in a reeducation in dealing with the world.

Relying on the inaccurate belief that all male homosexuals exhibit feminine characteristics, Adler felt that physical constitution plays a part in developing homosexuality on to the extent that a boy who is physically inadequate feels inferior. If he is weak, awkard or overdelicate, he may feel girlish. He may then feel that he isn't man enough to stand up to his environment, and become shy, clinging, and submissive. A girl who feels gawky, ugly, and undelicate doubts that she can master her world as a female, with female charm, seductiveness, and compliance. Soon such children may renounce their masculinity and femininity respectively, because they feel utterly hopeless about winning life as men and women.

A certain portion of homosexuals display characteristics of the opposite sex. Because they are noticeable, they are more subject to the disdain of heterosexuals. This increased pressure 
can increase disturbance. Adler both genexalized from the disturbed, confusing the symptom with the cause, and also used the visible homosexual as a representative of all homosexuals. By advocating the adjustment of the individual to the norms of a social majority, he denied the possibility of society being a reflection of all the people within is.

Adler played a large part in shaping the course that later therapy was to take. With his emphasis on social adaptation, he stressed short-term therapy, teaching proper social roles.

Carl Jung broke with Freud shortly after Adler diød, in 1912. He, too, felt Freud overstressed sexual instinct. Like Adler, he wanted to focus on present behavior and life aims. An important aspect of his analysis could have been supportive of homosexuality, but it eventually led him to the creation of another popular anti-homosexual stereotype. He said that much of what we tend to call feminine in a man---his "soft and emotional' life---is no more homosexual than is a woman's firm inner strength. But there is, he said, an unconscious feminine self in each man, and a masculine self in each woman. He said that western man is afraid of his "feminine weakness" and his "female shadow", but that the more he tries to keep them unconscious for his own comfort, the greater toll the avoidance exacts.

This could have been a basis for valuing expression of feminine and masculine qualities in both sexes. The expression of bi-sexuality could have become valued socially. Society could even have come to value men who expressed their femininity and women their masculinity, to the point of sexual action. However, 
Jung went on to say that many mothers consciously or unconsciously connive in creating their children's "deviance". The "mother complex", said Jung, can produce Don Juanism, impotence, or homosexuality. "The homosexual's masculinity is tied to his mother; Don Juan seeks his mother in every woman he meets". 79 The overprotective mother syndrome is one of the most frequently used explanations for homosexuality. Once again, the heterosexual therapist starts with the proposition that homosexuality is undesirable, then seeks explanation from the history of disturbed homosexual individuals.

WiIhelm Stekel, who also broke with Freud before the First World War, continued to assume homosexuality was deviant, and went further in confusing cause and effect, creating another explanation that would become fixed in popular ideology, He claimed all neuroses and sexual disorders rise from mental conflict, not blocked instinct, and are therefore potentially curable. Like Freud, he was incapable of validating a homosexual who was not disturbed. Such people, who seem free of conflict, and normal in all other respects, had completely sublimated their heterosexuality. All such people show disgust at the opposite sex. By this point psychoanalytic theory had completely dispensed with scientific accountability.

Like Freud, with his well adjusted lesbian patient, Stekel encountered a female transvestite who was completely satisfied with her "deviance". She wanted to get his help in obtaining a police permit to wear men's clothes. Over many sesssions, he symbclically analyzed her past, concluding that she renounced her femininity because she felt ugly: "Her injured narcissism 
found a way to pleasure and beauty----transvestism". 80

Sandor Ferenczi was the last of the early Freudians to devote a major analysis to homosexuality. In his Nosology of Male Homosexuality he contributed more anti-woman theory to the anti-homosexual trend of psychoanalysis. In distinguishing a "subject homosexual" and an "object homosexiral", he reaffirmed the responsibility of the mother. A subject homosexual loves his father, and an object homosexual has his heterosexual impulses punished by his mother. ${ }^{82}$ It's interesting that when these heterosexual male therapists mechanically inverted their male models to fit female homosexuals, they seldom went so far as to ascribe a comparable responsibility to the father. On the contrary, when some of the first long studies of lesbianism came out in the 1920 's, ${ }^{83}$ it was once again the mother's fault. Lesbianism was caused by obsession or fixation on the mother, due to inadequate warmth and attention from her. Some lesbians play the passive, submissive 1ittle girl, and get into mother/daughter relations with other women. Their sexual activity with other women make up for early deprivation in infantile gratification. Explaining everything, they found that some lesbians deny this need by playing the psychologically enslaving mother.

Around 1920, Freud was faced with a hiatus in his psychoananalytic theory and competition from the theories of his disciples. He developed his theory of the ego, ${ }^{84}$ which influenced 1 ater therapists. He said that a child starts out completely motivated by drives and instincts. He called this aspect of the mind the "id". As the child grows, the "ego" is developed through the 
construction of defenses: denial, repression, projection, reaction formation. This occurs when the child has a sense of being a separate entity. At the age of five or six, the "super-ego" is formed. This is the introjected parental voice. The child now is capable of greater self-regulation. Freud revised his thinking about anxiety. He now said that anxiety creates repression. This led to the development of Ego Psychology. Emphasis shifted to questions of how the ego develops, and how it may be affected by psychoanalysis.

Wilhelm Reich, who broke with Freud in 1932, developed the theory of character neurosis. ${ }^{85}$ This is a disorder consisting of ego defenses so stable that they seem a fixed part of the personality. Neither extreme nor acute, it is seen as maladaptive tendencies in the overall personality with which patients habitually defend themselves against others. ${ }^{86}$ Although Reich went on to claim that almost all disorders were the result of repressed sexuality, he saw this in completely heterosexual terms. The complete heterosexual orgasm was seen as the curative factor. ${ }^{87}$ Aided by his emphasis on physical mannerisms, he placed homosexuality in the category of a character neurosis.

A significant revision of Freud came about through the work of a number of female analysts. They included Anna Freud, Helene Deutsch, Clara Thompson, and Melanie Klein. They critized Freud's Victorian anti-feminine approach. They pointed to his theories of penis envy, the vulva as a wound, inadequate female superego, and the interpretation of the female Dedipal conflict as jealousy over boys' genitalia. Penis envy, they said, is in some cases as 
much male grandiosity as female reality. Girls' supergos are not lesser, just different. 88

It might be pointed out that this same line of reasoning may be applied to Freud's negative picture of homosexuality. Freud was reflecting the anti-homosexual values of his society, just as he reflected the anti-female. The supposed deviance of homosexuality could have been heterosexual grandiosity. The development of homosexuality may not be lesser, just different. The women psychiatrists never approached such a position. They often were responsible for many of the studies of lesbianism in Freudian terms.

The prominent theoreticians continued to focus largely on male homosexuality. Through the 1930's and 1940's, a body of explanations were advanced and taken as fact. ${ }^{89}$ Almost all of these were extensions of basic Freudian theory. There was little else to draw on, since no data from a sufficiently large population conducted along rigorous, scientific methods yet existed.

Homosexuality resulted when a boy identified with his mother, and wanted to be possessed by men as she was by the father. It resulted when the boy fantasized developing, as an adult, a feminine role in order to master other men. It developed when a boy had incestuous feelings for his sister, and seduced her boyfriends as a way of keeping her. A boy might become homosexual when he identified with his agressive parent, adopting the role of a cold mother, and, later, loving boys who represented himself. He might become homosexual to avoid the incestuousness of loving his mother and the consequent revenge of his father; in effect saying, "Don't worry about me, I'm not even male". Homosexuality 
might be latent heterosexuality blocked by fears of the castrating vulva. The homosexual boy might be saying, "Father, love me as you love mother", or "Mother, love me as you love sister". Homosexuality was also seen as a part of alcoholism, acute depression, and paranoia. The multitude of theories resulted because, in a homosexual with pathological history, it was the homosexuality which was examined, while in a heterosexual with pathological history, it was the pathology which was examined.

While psychiatrists were developing theories from the subjective information of their patients, scientists were making discoveries which came to play a part in the treatment of homosexuals .

\section{Other Sciences}

In 1889, Dx. Brown-Seguard announced in Paris that he had rejuvenated himself with injections of a filtered extract of dog testicles. Hi.s solution contained an element now called testosterone. 90 During the next few decades research began uncovering the system of hormonal and nervous-system mechanisms that control much of sexual development and behavior. In the 1920's Eugene Steinach said he had changed people's sex with hormones and surgery. 91 For the next few decades attempts were made to "cure" homosexuality with injections of testosterone or estrogen. The endocrine system proved to be more complex than realized. If a woman receives a small amount of testosterone, it stimulates her ovaries and affects her nervous system, increasing her sex drive. But with both heterosexuals and homosexuals, it does not change sexual orientation. With increased dosage there is a decrease in 
sex drive, and a change in secondary sexual characteristics toward those of the opposite sex. A similar pattern occurs in men receiving estrogen. 92 Though there was evidence against it, treatment of homosexuals with hormones continued. One pro-homosexual. use of hormones is the change of transexuals' physical characteristics in conjunction with surgery.

Another theory developed from objective observation was behaviorism. Its origins are in Ivan Pavlov's studies of the salivary responses of dogs. ${ }^{93}$ He discovered the principle of operant conditioning when he observed that a natural response to a natural stimulus, could be transferred to another stimulus. He went on to apply his theories to human behavior and psychotherapy. Pavlov's principle of conditioning was taken up by the American psychologist J.B. Watson, as a procedure for controlling human behavior through reward and punishment. The experiments of Pavlov and Watson use a form of behavior modification, now called "respondent" conditioning. Through the work of such people as E.L. Thorndike and B.F. Skinner, a second major form was developed, "operant" conditioning.

Both forms are used in techniques attempting to change a homosexual object to a heterosexual object choice. Examples of these techniques will be discussed later.

Respondent conditioning teaches a desired behavior by presenting a stimulus that is known to elicit a particulat response in the subject. Through conditioning, these same responses may be elicited by other stimuli. Repeated presentation of the secondary stimuli without the primary leads to "extinction" of 
the response.

In operant conditioning the subject is placed in a situation in which it learns to make a response that brings about attainment of a goal or satisfaction of a need. Reinforcement is the strengthening of a new response by its repeated association with a stimulus. The stimulus may be either positive or negative (adversive). The tendency for a response that has been conditioned to one stimulus, to become associated with other stimuli is "generalization".

Endocrine theory and behaviorism as applied to humans claim to be scientifically objective. Since they involve less speculative, subjective inference, they have not faced criticisms of bias as psychoanalysis has. Since under the blanket of objectivity, the question of values is less discussed, those values which produce and support the practicioners predominates. When endocrine theory and behaviorism have been used in the treatment of homosexuals (which has been often) the heterosexual bias of such treatment has gone unquestioned.

Kinsey

Research prior to Kinsey on what people do sexually, was incomplete and unreliable. At the time when ethnology was developing and experimental psychology was having greater success, Kinsey attempted to use the scientific methods to observe people that were bringing success in other areas.

Alfred Kinsey was a zoologist, specializing in research on the gall wasp. In trying to find answers to the questions on human sexuality asked by his students at Indiana University, he 
was surprised to find almost no data on the subject. What studies that existed used samples in the hundreds. Kinsey has used 150,000 individual wasps in his research.

Kinsey decided to use a taxonomic study of human sexuality (an attempt to find the range of variation of traits). Beginning in 1938, he was funded by Indiana University, and later by the Rockefeller Foundation. His primary collaborators were Wardell Pomeroy, Clyde Martin, and Paul Gebhard,

There was much initial opposition to the study. Some people threatened to prosecute or ban the study. Some scientists thought that only research on "normal" sex should be carried out. Psychoanalysts, psychologists, and gynecologists critized the strictly taxonomic methodology.

The study scrupulously tried to anticipate criticism, and correct for mistakes. The kinsey group interviewed a wide variety of the population. To avoid skewed samples, they attempted to interview all members of a club, church, prison, or town. Married people were interviewed separately to check on accuracy. People were interviewed numerous times. Much of the criticism eventually leveled against the study was anticipated in the published document. The long-term design foresaw 100,000 life histories with a minimum of 3,000 for each subgroup: age, sex, education, religion. The findings proved so significant that Kinsey decided to publish after gathering over 18,000 interview. He chose 5,300 femals and 6,300 males. Exclusions were based on incomplete knowledge of a subgroup. He published Sexual Behavior in the Human Male in 1948 and Sexual Behavior in the Human Female in 1953. The gulf between 
the morality promulgated by the state, the churches, and the psychiatric establishment, and the actual behavior of American men and women, was great. There was much public outrage about the findings. The biggest shock was regarding the incidence of homosexual behavior.

The findings contradicted Freud's pattern of progression from autoerotic to homosexual, to heterosexual development. The concept of sublimation was also proven unfounded.

With his emphasis on observing and reporting actual behavior, rather than creating exclusive generic labels, Kinsey had to scrap the terms heterosexual and homosexual as descriptions of people. He replaced them with a seven-point scale of behavior:

0 -- exclusively heterosexual experience, with no homoserual experience

1 -- predominantly heterosexual, only incidentally homos exual

2 -- predominantly heterosexual, but more than incidentally homosexual

3 -- equally heterosexual and homosexual

4 -- predominantly homosexual, but more than incidentally heterosexual

5 -- predominantly homosexual, but incidentally heterosexual

6 -- exclusively homosexual

About $18 \%$ of all males rated between 3 and 6 , as much homosexual as heterosexual, for at least three consecutive years of their lives. $13 \%$ rated between 4 and 6 , more homosexual, for three consecutive years. One male in ten rated 5 or 6 for at least three years. 
Kinsey a1so found that $37 \%$ of all males had a homosexual contact to orgasm after puberty. Finding this high, he rechecked the data several times. Each time it was confirmed.

Homosexual males had behavior patterns more similar to heterosexual male behavior patterns than to those of homosexual females. College educated men had the highest number. Men who worked in remote areas had higher rates of homosexual behavior-lumbermen, cattlemen, prospectors, miners and hunters. They nevertheless continued to think of themselves as heterosexual. The most anti-homosexual attitudes came from the level where there was the most homosexual behavior--high school graduates who were skilled laborers and low-level white collar workers. of this group, $45 \%$ had had one homosexual experience to orgasm by age nineteen.

Kinsey's study was significant because it shifted the understanding of homosexuality from something which totaliy defined an individual, to a description of a particular sexual activity. It gave the lie to the idea that homosexuality is a deviation engaged in by only a small number of people. It showed that it was engaged in by people who considered themselves "normal", even "heterosexual". It was also significant because the study was backed by the National Research Council, Indiana University, and the Rockefeller Foundation.

By 1950 , Kinsey's research group had received the highest honors, with nearly unanimous acclaim from reviewers, including sundry scientists in a dozen fields. The first book was recongnized as the most extensive effort ever made to gather and present data 
on what feople do sexually. The report had 804 pages of intricated prose, concerning 5,300 males whose activities were charted in 335 graphs and tables.

In spite of the acclaim the research received, there was strong opposition to the findings from a small number of people who were able to exert great pressure. Dr. Harold Dodds, president of Princeton University, wrote a critique for the Reader's Digest in which he compared the work to "toilet wall inscriptions". 94 Dodds and a Baptist minister secretly organized public pressure against Kinsey. Professor Helen Bond of Columbia University suggested that "there should be a law against doing research exclusively with sex". 95 Dr. A. H. Hobbs, from the University of Pennsylvania, charged that there must be something wrong with Kinsey's statistics and that the prestige of the Rockefeller Foundation gave unwarranted weight to implications "that homosexuality is normal and that premarital relations might be a good thing". 96

These influential opponents organized a letter campaign to the three financial backers. Indiana University renewed its support, but the other two were swayed by the letters and the political climate. In 1952, the Rockefeller Foundation asked Kinsey not to acknowledge their support in Sexual Behavjor in the Human Female. Kinsey refused the request.

A group led by Hobbs complained to Congress that "tax-free philanthropic and educational foundations are weilding powerful adverse effects on morality". Representative Reece formed a "House Committee to Investigate Tax-Exempt Foundations". Reece 
announced that he would not hear testimony from Kinsey or his supporters. Fow sixteen sessions the committee heard adverse testimony from twelve witnesses (who were hand picked, as Reps. Gracie post and Wayne Hays later revealed). 97

The final witness, who was supposed to testify against Kinsey, proceeded to give evidence that, as Hays later said, "began to destroy with facts all the staff testimony". 98 Reece interrupted the witness in mid-testimony. He closed all hearings to the public and refused to hear any defense witnesses, even in private.

Although the Rockefeller Foundation supported Kinsey in its written report to the committee, it withdrew its backing afterwaras. It clajmed that Kinsey had not requested renewal, and that his research team was well endowed. Both statement were untrue.

It is perhaps most surprising that an objective report on the prevalence of homosexuality was supported, made public, and widely praised. It was the hostile critics who finally broke the research on sexuality. Kinsey died while trying to raise funds shortly after the Rockefeller Foundation withdrew. The Kinsey Foundation went on, being funded by the government. Its approach changed to that of validating pre-existing theories.

The example of Kinsey has motivated some later researchers to take a similarly exhaustive, objective approach to the study of sexuality. It did not prevent studies based on unfounded anti-homosexual biases. It also had little effect on the attempts, some of them brutal, of science, to change individual's homosexual orientation. The methods of a century of treatment continued despite the fact that they had been largely unsuccessful. 
Traatrient

The txeatment of homosexuality had included surgical measures: vasectoniy, hysterectomy, and castration. In the late $1880^{\prime} \mathrm{s}$, medical journals discussed surgical removal of the ovaries and of the clitoris as curses for female "erotomania", including lesbianism. Lobotomy was performed as late as 1951. 99 Many forms of chemotherapy have been used, including hormones, ISD, sexual stimulants, and depressants. Hypnosis for homosexuality was used as early as 1899, and as late as 1967 . Other methods used are shock treatment (electric and chemical), aversion therapy, emetics, drugs, and negative verba] suggestion. Sensitization, using pornographic photographs to arouse heterosexual feelings, has been used. Also, homosexuals have undergone psychoanalysis and other modes of individual and group therapy. Some practicioners have urged will power and sexual abstinence. Many new treatment modalities clains of cures, but few are substantiated. Meanwhile, homosexual men and women have undergone a century of physical and mental. anguish.

In the 1880's hysterics and epileptics of both sexes were surgically castrated--hundreds by one doctor alone. Theories vaguely correfted convulsive disorders, the gonads, and sexual activity. Cauterization of the clitoris was prescribed for "excessive nasturbation" in females. In the $1890^{\prime} \mathrm{s}$, as degeneracy theories became more accepted, castration was widely practiced, to prevent the passing on of deviant genes, and by reducing sexual. drive, to end masturbation, rape, child molestation, and homosexuestity. 
Arcund 1895, E. Hoyt Pilcher, head of a Kansas institution for the feeble minded, allowed four boys and fourteen girls, all "confirmed masturbators", to be castrated. He had no right to do so, but was convinced that it would prevent "excessive masturbation and pervert sexual acts". 100

In 1898, a Kansas asylum reported that forty-eight young men had been castrated to prevent them from fathering degenerate children. ${ }^{101}$ A physician at the hospital for epileptics in Palmer, Massachusetts castrated twenty-four males, half younger than fourteen, for persistent masturbation and epilepsy. 102

In a paper read before the American Prison Association, Dr. Harry Sharp of Indiana State Reformatory announced that he had developed a new method for sterilizing inmates: vasectomy. By 1909 he had experimented on 236 people, claiming that the subject becomes "of a more sunny disposition, brighter of intellect, ceases excessive masturbation". 103 He saw this as a way to eliminate the insane, epileptics, mentally retarded, alcoholics, criminals, sexually deviants, paupers, and tramps.

Indiana passed an eugenic sterilization bill in 1907. Washington, Oregon and California followed suit in 1909. Indiana had performed 873 sterilizations before the law was declared unconstitutional. By 1929, twenty-two states had sterilization laws. Claims were made that deviants were "pacified" and "resocialized" by the operation. (Similar claims were made for lobotomization after its introduction in 1936). Justice Oliver Wendell. Holmes upheld a sterilization law, writing that "the principle that sustains compulsory vaccination is broad enough to cover cutting the fallopian tubes. Three generations of 
imbeciles are enough". 104

In 1950, the director of the Winfield, Kansas State Training School argued that castration had recently made 330 males at the institute more stable and peaceful, less a "social menace". 105 Eleven states still had involuntary sterilization laws on their books, and twenty more allowed it on a voluntary basis.

The American Neurological Association Committee for the Investigation of Sterilization advocated use of asexualization in 1950. There had been some fifty thousand sterilizations on record, and probably many more unrecorded.

In 1914, Dr. Charles $H$. Huges reported the favorable results of a castration of a "gentleman of ordinary moral, intellectual, and physical parts, and psychic compulsions, save for the affliction which distinguished him". 106

In 1953, Bowman and Engle at the Langley Porter Clinic in San Francisco published "The Problem of Homosexuality" in The Journal of Social Hygiene. In it they summarized the generally ineffective attempts to treat homosexuality with electro-andpharmacological shock. They then discussed the more positire potential of castration, noting that European therapists "found a distinct reduction of desire, so that castrates have been able to avoid further sexual crimes".

In the late 19th and early 20th century sexual deviants were experimented on with a number of methods. A St. Louis medical journal published an article in 1904 describing an operation on a "competent accountant and a cultured gentleman". The pubfic nerve to the peris wris severed, "but the rnorbid 
inclination still persists". The physician concluded, "This case appears to be in the head and not in the genitals". 107 Many practicioners believed firmly in the hormonal imbalance theory of homosexuality. Dr. LaForest Potter reported, in 1933, the case of a lesbian "whose psychology was subsequently modified by argument, and whose libido was brought back to normal by stimulation of the ovaries and thyroid, and by the internal administration of ovarian substance and corpus luteum". ${ }^{108} \mathrm{He}$ discussed a male homosexual musician. He prescribed for him "certain endocine stimulation and other adjunct treatment". He then suggested that the young man sublimate his "excessive sexual urge" into his music. Dr. Potter found that, "today, all the suffering of his soul he pours out through his violin". He felt it was a sharne Oscar Wilde was born too early, for "were he willing to cooperate ... we could have subjected the overactive thymus to $x$-ray radiation, atrophied the gland and suppressed the overactivity of its function -.- which was one of the principle causes of Wilde's lack of sexual normality".

He ends with a plea for research into treatment of all. "abnormals". "Some we would probably kill. Others we would cure ... all of which would go far in helping to build hope, happiness, kindness, love, tolerance, and understanding, in millions of human beings who are only waiting for the light that shall disclose all these blessings to them".

In 194], a psychologist and an endocrinologist from Worcester, Massachusetts published an account of a homonal treatment of homosexuality. 109 They began by thanking varicus pharmaceutical companies for supplying the experimental hormones: Squitb, Schering. 
Ayerst, McKenna and Harrison, Lily. They made "an empirical test of the influence of sex hormones upon attitudes and behavior" of a 46-year-old black male, who had been in state mental hospitals for twenty years. His original diagnosis had been "constitutional psychopathic with psychosis". The first symtoms of disturbance were "seclusiveness, shyness, pronounced effeminacy, and excessive preoccupation with drawing, painting, designing of women's clothes and similar "artistic" activities". They found "mental deficiency, if present, is of a high grade or borderline degree". Sex hormone treatment ran from October 1939 to April 1940. He was given a sequence of hormones: "the potent synthetic estrogen, Stilboestrol (squibb), in dosage of $5 \mathrm{mgm}$. three times a week; 150 milligram tablets of Testosterone (Schering), imbedded in the subcutaneous tissues beneath the inferior angle of the left scapula; intramuscular injections of a gonadotropic preparation derived from pregnate-mare serum (Anteron-Schering). The dosage was 1 cc or 250 units weekly; desicated thyroid (Armour) at 1 grain daily; Pituitary Gonadotropic Pranteron (Schering), in dosage of 1 cc twice weekly; Testosterone Propionate by intramuscular jnjection was begun in dosage of $50 \mathrm{mgm}$. twice a week; another estrogenic preparation, Emmenin, being used in dosage of ]. teaspoonful three times daily; another estrogen, Estriol (Lilly), was given in the large dosage, $0.24 \mathrm{mgm}$. three times daily". "As is well know, Stilboestrol has a tendency to produce nausea and even vomiting. The patient experienced a certain amount of nausea but not enough to warrant discontinuing of the medication. This effect aside, none of the drugs of the entire series gave rise to any detectable change of behavior or attitude". 
In 1937, Dr. Owensby of Atlanta, Georgia, began treating male and female homosexuals by convulsive shock inducted with Metrozol, a chemical stimulant. He reported to the Southern Psychiatric Association in 1940. Concerning treatment, Dr. Owensby received responses from homosexuals which he found striking: "Paradoxical as it may be, every male homosexual I have talked with made the unequivocal statement that he had no desire to change his sexual habits and that those who did were motivated by an attempt to escape the peralty exacted by society for homosexual practices".110

Dr Owensby presented six treatment histories in the Journal of Nervous and Mental Diseases. In Case One, a 19-year-old white male was arrested for homosexuality. He was paroled for treatment, and promised a pardon if it was successful. "Metrozol was administered until fifteen shocks were produced. All homosexual desires had disappeared after the ninth shock, but treatment was continled until all feminine mannerisms had been renover." Eighteen months later, he received a pardon.

Case Two was of a 34-year-old white male who admitted his only reason for seeking treatment "was fear of exposure and subsequent disgrace". All homosexual desire disappeared at sever grand mal attacks induced by Metrozol.

Next was the case of a 44 -year-old white male, most of whose life had been spent in jail for homosexuality. He was proud that his was a "man-woman" complex. Ten grand mal attacks were indued vith Metrozo1. Owensby reported that he "appeared to be regenerated after the ninth seizure".

The fourth case was of a reclusive male who would take trips to other cities for homosexual encounters. He was cured 
after six grand mal seizures.

Case Five was a 26-year-old white male who was cured after six grand mal attacks.

The sixth case was of a 24-year-old white lesbian experiencing ten grand mal seizures. After this, she became infatuated with an intern, and "appeared to be healthy in every way".

Dr. Owensby's apparent success in correcting homosexuality has not been duplicated. Reporting in the Journal of Nervous and Mental Diseases for 1949, Dr. George N. Thompson concluded on the basis of six case histories that Matrozol-induced shock has no effect on sexual orientation.

Chemical shock gave way to the common practice of electric shock treatment. Since this method has been, and continues to be, widely used, there is no accurate method of how many homosexuals have received it. While there are some written reports of its use on homosexuals, the actual extent is probably much greater.

The theory behind shock treatment is that an interruption in neural impulses produced a dimunition of nervous disturbarce. It was first developed after observations that epileptics experienced a period of tranquility after seizures. The use of shock dimirished somewhat, after the introduction of psychotropic drugs in the late $1950^{\prime} \mathrm{s}$. It is still used extensively, however, with patients receiving multiple shocks that sometimes total into the hundreds. It was not until the 1960's that anesthetic and muscle-relaxant drugs were used with the treatments. Prior to this it was a painful, traumatic experience. There is no 
accurate data as to the effect of electro-convilsive treatment, and no theory as to the nature of its therapeutic properties. It is believed to be indicated in cases of both severe depressions and hyperactivity.

In an article called, "Homosexuality, Transvestism, and Psychosis", Dr. Samuel Liebman presented, in 1944, the case study of a young Black male homosexual transvestite. ${ }^{11}$ He had feninine attire and mannerisms. "He spoke rather freely of his homosexuality". His background was normal until he adopted the effeminate manner. The report commented that in high school "he attempted to attend activities which other boys did not... As he grew older, however, the color line became more marked, and the patient seemed to withdraw and had no close friends..."

Although the report mentions some grandiose speech, there is much description of his effeminacy and the fact that "he constantly annoyed the personnel". He was given eight shock treatments. The conclusion was that "with electroshock therapy, the patient recovered from his psychosiss and transvestism, although he remained overtly homosexual". The treatment was seen as successful, despite the fact that, in contrast to his prior attitude, "the main picture was that of an apathetically depressed individual".

In an interview in 1.974 , a young male homosexual told of his commitment and shock treatment ten years before. ${ }^{112}$. His parents' desire to cure his homosexuality was the reason for his confinement, and shock treatment. His parents arranged the committment after he received a postcard from a male lover. 
Released after a few months, his parents had hjm committed again. He was twenty-two years old. His mother now thinks that is was a mistake. She had felt responsible for his homosexuality.

He received seventeen shock treatments. He describes the effect: "I remember thinking, "Isn't that strange? I can't move!" I thought, "Why is he shaving me, and where am $I$, and why can't I do it myself, and why can't I stand up, and why can't I move my arms?'"' He remembers hearing others getting shock treatment: "You hear that horrible scream. There's one loud scream". He had two doctors, one of whom said there was nothing wrong with being gay. The other one screamed at him that he was sick.

He feels the worst part of electric shock is the amnesia and depression which plagued him for the next eight years. He could not remember many of his former friends. He would suddenly find that he did not know where he was. He describes that as an agony of uncertainty.

Lobotomy (surgical sectioning of tracts of white matter between the pre-frontal lobe and the thalamus) is rarely used now. However, it was widely practiced in the past on mental patients. There are some reports of its use in the treatment of homosexuality. In 1942, Drs. R. S. Banay and L. Davidoff of New York reported in the Journal of Criminal Psychopathology on the "apparent recovery of a sex psychopath after lobotomy". Within a few years, Dr. Banay was obliged to revise his positive post-operative evaluation. In 1948, Banay collaborated with Dr. J. W. Friendlander of Chicago on a follow-up study of the same patient entitled "Psychosis Following Lobotomy in a Case of Sexual Psychopathy". 
The patient was employed as a secretary. He was arrested for sexual activity with a small boy at the age of 52 . His history also included a masochistic interest in being beaten. The doctors reported that a year of psychotherapy brought no relief. "Lobotomy was recommended because his history justified his fears (?), his symptoms included tension, depressirn, obsession and compulsion, and he was otherwise incorrigible". 113 He was confused, disoriented, incontinent, and euphoric after the operation. Prior to the operation he had "no delusion, hallucinations, or defect in sensorium. Intelligence was bright normal, or even superior".

After his release he deteriorated. He lost several jobs because he was "cheerfully incompetent". He ended up several. years after release in a flop, incontinent and bugridden, completely unable to care for himself. He apparently still had masochistic and homosexual inclinations. The physicians concluded: "Our patient showed rapid improvement after the immediate post-operaiive period, stabilization for a year, and then progressive decline. Lobotomized in November, 1941, he was first recognized as psychotic in Mrarch, 1945, and demented in January, 1947. Since there is no evidence for any complicating factor, and we can explain all our findings in terms of the effects of the operation itself, we conclude that the lobotomy produced the dementis".

In Psychiatric Quarterly in 1959, Drs. Zlotow and Paganini presented' the first large scale follow-up study of the effects of lobotomy on sexual behavior. Their report was based upon observation and comparison of the pre- and post-operative "erotic manifestations" of 1.00 lobotomized males, selected at 
randon from the patients at Pilgrim State Hospital, New York. Homosexual and autoerotic activity are reported as a management problem leading to the patients' lobotomization. The authors presented a number of representative case studies. One was of a male admitted to the state hospital in 1931 at the age of twentyone.

He was diagnosed as paranoid. He had engaged in homosexual activities and began hearing voices calling him a "fairy". He became impotent. In 1951, he had a prefrontal lobotomy. "For approximately two years afterward, the patient showed considerable improvement in behavior. He became quite and well behaved, but was still hallucinatory". They go on to report that about two years still later, the patient "participated in all types of homoerotic and autoerotic manifestations. This patient has shown an increase in his sexual manifestations after operation".

Another patient had engaged in masturbation and fellatio. He was lobotomized in 1951. After this no sexual deviations were reported, but the patient admitted that he occasionally masturbated.

A third report was of a person who showed no sexual deviance, but who was lobotomized in 1947 because of his "assualtive tendencies". After the operation the patient was openly autoerotic and made homosexual advances on other patients.

Zlotow and Paganini summarized their findings. Sixty percent of the sample showed autoerotic and homoerotic manifestations five years after lobotomy. Two-thirds showed such activity before the operation. They felt that the rest disgused such tendencies as aggression prior to the operation. Therefore lobotomy did not result in new behavior. Lobotomy in most cases 
does not change sexual behavior, they concluded.

The treatment most directly affecting homosexuals is aversion therapy. In its various forms it has been advanced in the past few decades as the answer to the "problem" of homosexuality.

The first documented use of aversion therapy on a homosexual was a report given by Dr. Louis W. Max, of New York University, to the American Psychological Association, on "Breaking Up a Homosexual Fixation by the Conditioned Reaction Technique" in 1935. Finding that a homosexual neurosis in a young man involved a fetishistic reaction to a stimulus, he coupled the stimulus with electric shock. At first there was 1ittle effect, "but intensities higher than those usually employed on human subjects...definitely diminished the emotional value of the stimulus for days after each experimental period". Four months after cessation of the treatment, the patient reported that he was $95 \%$ cured.

The next article on conditional-reflex therapy was published in the International Journal of Sexology in 1953. This was an influential report on the work of the Czech doctors V. Srnec and Kurt Freund. They pioneered the use of slides with emetics to produce aversion to homosexuality and heterosexual arousal.

They described two phases of treatment. The subject is given emetine orally, then on injection of emetine, apomorphine, pilocarpine, and ephidrine. He is then shown films and slides of increasingly undressed males, as his nausea and vomiting increase. In the second phase, films of women are shown in situations which "would rouse sexual appetite in normal men". 
These films are shown in the evening before bedtime on a day when the subject was injected with testosterone in the morning. This is repeated five to ten times. Of the twenty-five subjects, ten became heterosexual, three became asexual, and twelve remained as they had been.

A 1963 article in the Journal of the National Medical Association reported the use of hypnosis in an aversive model. The practicioner, Dr. Miller, claimed to "create deep aversion in the male homosexual to the male body". He reported on the treatment of three bisexuals and one exclusive homosexual. He stated that many effeminate homosexuals are highly sensitive to smell, taste, and touch. "Like females, they are particularly sensitive to body odors, and use deodorants and perfumes extensivel.y". Relying on this he hypnotically regressed his patients to re-experience their most pronounced disgust reactions. Then post-hypnotic suggestion linked these reactions with the male body. One man experienced the loss of all sexual response and in increased tension. He later developed sexual interest in a female friend, which was encouraged during hypnosis. Dr. Miller concludes by saying that aversion to men dosen't alter the basic attraction, but makes possible the development of heterosexual interest.

Joseph $\mathrm{K}$. Cautela introduced a new variation of aversion therapy, covert sensitization, in an article in Psychological Reports in 1967. 114 Covert is used because verbal suggestion replaces such overt stinuli as photo, films, emetics, shock. Sensitization refers to the creation in the patient of "an 
avoidance response to the undesirable stimulus. One essentially builds up a hierarchy of the desirable sexual objects and the available contacts of likely sexual stimulation. Covert sensitization is applied to all items in the hierarchy, with the most desirable sexual object being treated first".

He had only treated two people at the time of the report. One was a young male who subsequently was not reported to have engaged in homosexual activity. The second was of a serviceman who experienced vicarious homosexual fantasies. This was reduced to "about four temptations a week which last about a second".

Behaviorist treatment of a lesbian is described in Psychological Reports in 1970. ${ }^{115}$ The study was carried out by Ivan Toby Rutner at the Behavioral Research Unit at Jacksonville State Hospital in Illinois. He combined covert sensitization to increase anxiety about homosexuality with desensitization to reduce anxiety about heterosexuality.

The subject was a 20-year-old woman, who had engaged in homosexual activity for about four years. She voluntarily hospitalized herself to get rid of her homosexual inclinations. The treatment was begun after baseline data was obtained about the frequency of homosexual desires. Suggestion was given her that she fantasize homosexual encounters, then nausea, and departure, followed by relief. She was taught to give herself these suggestions, and told to go through this process fives times a day.

The next step consisted of desensitization to men. A hierarchy of anxiety-producing situation was constructed. She 
went through these in two sessions, arriving at the point where she could tolerate being kissed and hugged by^many. The two stages were cominined in a chird stage. Two months later, she had had no homosexual experiences. However, two months after this she had once again engaged exclusively in homosexual behavior. The report concluded that this was because no reinforcement was made available and the heterosexual behavior was extinguished.

These examples are but a few of the cases of individuals treated with the more mechanical, physical (often painful, sometimes physiologically damaging) methods of "curing" homosexuality. While a great many individuals fell under the sway of practicioners of these methods, many more homosexuals have been treated with seemingly benign methods.

In the early days some physicians suggested abstinence, but the most common inethods for treating homosexuality has been psychornalysis. One of the most ignored opinions of Freud's by later follcwers of poychoanalysis, was his suggestion that homosexuals cannot change. Individually and in groups, psychoanalysis has beer applied to homosexuals from Freud's time to the present. While not physically painful or destructive, we might question the psychological pain and damage done to individuals who, rather than being supported for their sexual orientation, have been implicitly (and explicitly) critized for it. Psychoanalysis has acted on the assumption that heterosexuality is the only normal sexual expression. As has been indicated, it is at least open to question whether psychoanalysts have not merely been one of the more active promoters of a societal bias against 
a harmless minority.

Recent Theory

The tendency of psychoanalysis to want to change homosexuals into heterosexuals did not end when Kinsey demonstrated how widespread homosexual activities actually were. Beginning close on the heels of the publication of Kinsey's second book some psychoanalysts attempted a study which would identify the sources of homosexuality, and offer proof of a cure. Eight psychoanalysts and a psychologist, led by Dr. Irving Bieber, worked on their own time with little funding. Their purpose was to apply scientific methods in a systematic way, to the psychoanalytic approach to changing homosexuals. The result was the publication in 1962 of Homosexuality: A Psychoanalytic Study of Male Homosexua1s. 116

In 1952, Bieber and other members of the Society of Medical Psychoanalysts formed a research committee to study male homosexuality with analytic tools. They had seventy psychoanalysts answer questionaires about homosexual patients and comparison cases. They ended up with several runs of information on 106 homosexuals and 100 comparisons, the two groups matched fur age, incorre, education, and problems other than homosexuelity.

Bieber found that a majority of his homosexual subjects were only children or only sons. Their mothers tended to relate poorly to women. He used the term "close-binding-intimate" (CBI) for domineering mothers. He found $70 \%$ of his homosexuals subjects to such mothers. His description of the CBI was that she is emotionally-physically seductive to her son. He was her confidante. 
At the same time, she inhitited her son with anti-sexual attitudes, interfering with heterosexual activities. This double bind is why, for Bieber, homosexuals experience anxiety at the possibility of heterosexual contact. The mother both pampered her son and discouraged assertion and masculine behavior. Almost $79 \%$ of his subjects had emotionally detached fathers. He acted out male rivalry problems with his son. They stifled. attempts at self-assertion. Bieber wrote, "We have come to the conclusion that a constructive, supportive, warmly related father precludes the possibility of a homosexual son; also, Bieber found, a good relationship with a sibling might tip the scales in favor of heterosexuaiity. More homosexuals hated, but compared themselves to, brothers. He said effeminacy developed as an attempt to rival a sister.

He found a small number of mothers who were hostile to their sons, inspiring some aggressiveness. He found these subjects having more heterosexual potential. Of the homosexuals, $75 \%$ had been fearful of physical injury, $80 \%$ avoided fights, $65 \%$ were lone wolves, and $35 \%$ played mostly with girls.

Bieber interpreted this as fear of castration. He said fear and timidity were a protective camouflage of assertion, rising from Oedipal conflict. He concluded that "every homosexual is, in reality, a latent heteroseual". He found that the prescense of heterosexual content in the homosexual's thoughts and dreams supported this contention.

When his book was published, Bieber was critized from several different sides. Traditional psychoanalysts agreed that 
homosexuality is a disease, but refused to believe that it could be cured. Behaviorists doubted it could be cured by psychoanalysis. There was also a growing number of professionals who questioned the basic assumption and methods of the study.

Bieber makes two claims; that homosexuality is itself a disease; and that it is always associated with other clinical symptoms. The former cannot be deduced from scientific evidence because it is basically a matter of attaching a label (mental illness) to a particular sexual orientation (homosexuality). The second claim has been empirically refuted.

Bieber's methodology is open to basic questioning, since he assumed homosexuality as abnormal before the study was begun. He wrote, "We consider homosexuality to be a pathological biosocial, psychosexual adaption consequent to pervasive fears surrounding the expression of heterosexual impulses". This bias slanted the terminology used in the questionaire, and lends some skepticism to the findings.

The notion that bisexuality is inherited was critized in 1940 by Sandor Rado. What he did, though, was to eliminate the homosexuality aspect of inherited bisexuality and leave an inherited heterosexuality. It is this tradition that Bieber followed. Another methodological criticism relates to this general tendency in psychoanalysis. Rather than testing objective phenomena, Bieber merely tested the subjective interpretations of a small group of psychoanalysts.

Another major criticism is that Bieber generalizes from the disturbed. Any inquiry that seeks to use only one kind of 
data to the exclusion of other data, in order to substantiate a preconceived notion, is not scientific. Also, such data may be used to support other conclusions which Bieber had rejected without grounds. It is a tautology to say that those in psychiatric treatment are mentally ill. Homosexual behavior often is a symptom or part of illness, but so is heterosexual behavior. To claim representation for a sample which is not representative of the whole population leads to problems. It dosen't account for the $32 \%$ of Bieber's sample of heterosexuals who had "close-binding-intimate" mothers; or the $54 \%$ who had detached fathers. It also dosen't account for the enormous number of men who are able to have satisfactory relations with both men and women during part of their lives. Nor does it apply to the happy, well adjusted homosexual.

The study basically upholds some common stereotypes and operates within narrow sex role definitions. Many kinds of disturbance are blamed on the influence of the mother. But nowhere is it examined why women have been given such predominant responsibility for children, and how the limitations in this role can lead them to focus on this contact with children in destructive ways.

If there were none of these problems with the Bieber study, one problem would remain. There is an explicit attempt to support the assertion that Bieber's findings offer a cure for homosexuality. A large percentage of those he says gave up homosexuality were already bisexual. In order to effect their change, they had to undergo some 350 hours each of psychoanalysis, 
which cost around $\$ 10,000$. Were this at all possible to apply to very many homosexuals, there would still be the difficulty that most homosexuals do not want to change. It is difficult to see in what sense Bieber's study can have much affect on the prescense of homosexuality.

Despite these rather transparent flaws, the study has been widely praised and is still influential in psychiatric circles. 117 It gave an impression of scientific certainty to counter Kinsey, and maintain the practice of treating homosexuality as a mental illness.

Criticism

Criticism of Bieber has raised the point of who determines the nature of mental illness. Is it a social definition, with the psychiatric establishment has been empower to make, merely because they all agree with each other? While there is a great deal of uniformity in the clinical world concerning mental illness, and homosexuality, there are some professionals who follow a different theoretical and practical assumption.

Thomas Szaz has been the most critical professional of psychiatric practices. In several books and articles, he has called into question the concept of mental illness and analyzed its societal function. 118 In The Manufacture of Madness, he finds the position on homosexuality the most telling example of the uses made of the concept of madness.

He examines the change from theology to science as forces in society, and the consequent relabeling of sin as sickness. He believes that the idea of madness replaced heresy. He finds this 
particularly relevant to the concept of sexual deviancy. He affirms the occurence of homosexuality amongst higher apes and humans, living in a wide variety of cultural conditions. He discusses the Biblical prohibitions against sodomy, its influence in the Middle Ages, and effect on contemporary lives, laws, and social attitudes. He finds that heresy and sexual deviancy became synonymous. Once people were labeled sexually and religiously deviant, they became non-people. All contradictory personal characteristics were eclipsed by the label. He says the disease called "mental illness" and "homosexuality" perform the same function today. "Like medieval heretics, men labeled "homosexual" are somehow totally bad". 119 We need no longer worry about the outsider as a person with rights and talents.

Szaz has often criticized the use of the medical model in mental and emotional disturbance. "Disease as a bilogical condition and as a social role are confused". He says that by pretending that convention is Nature, that disobeying a personal prohibition is a medical illness, psychiatrists establish themselves as agents of social control, disguised as medical practice". In short, psychiatric heresy, like religious heresy, is a functional concept. It is useful for the society that employs it; were it not so, the concept would never have evolved and would not continue to receive popular support".

He says that the "rhetoric of therapy" drowns the protests of socially persecuted individuals, just as the "rhetoric of salvation" drowned out the cries of the heretics. In asserting that the diagnosis is actually but a stigmatizing label, he points 
to the fact that Benjamin Rash "prcposed that Negroes had black skin because they were ill; and he uses their illness as a justification for their social control". He finds that the idea of a "madman" allows people to treat the person as the "other" and not as the "self".

He quotes Kar1 Menninger, "We cannot exto1 homosexuality. We do not, like some, condone it. We regard it as a symptom". Szaz says, "If homosexuality is a "symptom", what is there to "condone" or not "condont"?" This indicates that the medical role covers a role as moralist and social engineer.

He goes on to suggest that the psychiatric profession has a eed to see the homosexual as sick in order to preserve its own profession and prestige. Opposition to the enemy is a mark of faith. He points to the fact that people usually admit they are physically ill, and seek treatment; while most homosexuals do not consider themselves "mentally ill", and are often forced to undergo treatment.

He concludes by criticizing the combination of religious or medical ideas with political power. If they truly are beneficial, there is no reason to force them on people. He praises the separation of church and state in the U.S., and suggests similar provisions be made separating medical practice and state power.

There is growing criticism amongst professionals of traditional therapy goals. While recent theory often leads to greater acceptance of homosexuality, it usually dosen't discuss it directly. Few members of the profession have gone so far as to call into question the very basis of mental health care, as Szaz does. While many therapists are limiting their therapy to those 
who want to change, or helping with problems of adjustment, there has not yet been any extensive theory from a pro-homosexual perspective. There is also no major theoretical input from admittedly homosexual members of the profession.

In recent years, perspectives by and about homosexuals have appeared from non-professionals writing in gay liberation literature. They take the form of theory and personal accounts of experiences in therapy. One such article was published by a member of the Chicago Gay Liberation Front. ${ }^{120^{\circ}}$

He critizes the "establishment school of psychiatry" for their emphasis on adjustment. He sees this as encouraging homosexuals to make themselves appear heterosexual, settle for housing in a gay ghetto, accept a gay profession, and live with low self-esteem. He finds that the anti-homosexual attitude of society, which is the cause of the homosexuals' trouble, goes unchallenged".

In looking at the idea of appropriate gender identity, he asks who determined appropriateness. He concludes by stating that "homosexuality is at least on a par with heterosexuality as a way for people to relate to each other".

Christopher $Z$. Hobson has written an account of his nine years in therapy. 121 He had three therapists, who were al1 "intelligent, somewhat sensitive men". He went to them convinced that his homosexuality meant that he was mentally ill. They did not openly put forth the idea that homosexuality is a mental illness, but "their treatment contributed nothing to my awareness of myself, and even retarded it". 
He had sought psychotherapy because he wanted to be heterosexual. After four years of therapy nothing had changed. In his teens he had not been a happy homosexual. He was guilty about masturbation and about homosexuality, thinking about suicide, and having passionate friendships with heterosexual males.

He says that while in therapy he looked for the factors that caused his homosexuality. It didn't occur to hem that no one asked what caused heterosexuality; or that the two questions were comparable. He and his therapists explored his "guilt, eagerness for punishment, combined with eagerness for acceptance". They never looked at social attitudes, which might foster such feelings. Twice while in therapy he shunned homosexual contacts. His therapists, rather than explore what made him feel so guilty, saw this as evidence that he did not want to be a homosexual.

When he was making love with a man he felt harmonious and natural, not sick. His therapists never encouraged him to explore this contradiction. This was not mrer non-directiveness on the part of his therapists. He had directive therapists also.

He found that his fear and dislike for women, which his therapists often discussed, changed when he accepted his homosexuality, and no longer felt he was supposed to relate to women primarily sexually. When he was seeing his last therapist he had started being involved in "gay liberation". I insisted that if no positive value were placed on the dominant pattern (heterosexuality), then the deviant manifestation (homosexuality), had to be viewed not as a psychopathology, but as a manifestation of 
a pattern which might be in the absence of social pressures, be as fulfilling, or more fulfilling, than the dominant one. In conclusion, he says he will "stand on that standard so regularly invoked by psychotherapists themselves, success. In my opinion. I am healthier now... and I have only my life to offer as evidence that my choice was correct".

Articless such as these are part of a recent trend of homosexual organizations, to attack the traditional attitudes of the mental health system. There have been some significant changes as a result of this. The American Psychiatric Association

In June, 1970, twenty women's Iiberation people, and fifteen gay liberation people, went to the convention of the American Psychiatric Association. During presentations, including a report by Dr. Bieber, and a description of arersion therapy by Dr. Nathaniel McConaghy, the demonstrators heckled and disrupted the proceedings. The presentations were oalled off before schedule. Afterwards the homosexuals talked with angry psychiatrists about their damaging experiences in therapy. 122 Similar demonstrations were repeated in following years. A sma11 influential group of psychiatrists became sympathetic.

For almost one hundred years homosexulity had been classified as sexual deviation in the Association's "Diagnostic and Statistical Manual of Mental Disorders". On February 9, 1973 the eight-menber Committee on Nomenclature met to determine whether homosexuality should be eliminated from the 1 ist of mental disorders. The Gay Activist Allience presented the results of 
studies, showing the prescence of a large number of well adjusted homosexuals. Dr. Judd Marmor, vice president of the A.P.A., said homosexuality is not a mental illness. Dr. Brill, chairman of the Conmittee, supported elimination of homosexuality from the list. ${ }^{123}$

At the 126th annual convention in May, 1973, Irving Bieber said that while homosexuality shouldn't be categorized as a disease, studies "leave us no doubt that homosexuality is not normal". 124

Speaking at the convention Dr. Marmor said that the existing classification turns psychiatrists into agents of cultural value systems .

On December 15, 1973, the organization's Policy Board voted 13 to 0 to eliminate homosexuality from its list of mental illnesses. They replaced it with the category, "Sexual orientation disturbance". They agreed that "by itself, homosexuality does not meet the criteria for being a psychiatric disorder". Their definition for sexual orientation disturbance is, "individuals whose sexual interests are directed toward people of their own sex, and who are either disturbed by, in conflict with, or wish to change their sexual orientation". 125

The major breakthrough in the official attitude of the Psychiatric establishment was, as Dr. Alfred Freedman, President of the A.F.A., said "fanned by the organized homosexual community, which has vigorously protested the prejudice that derives from classifying their condition as a mental illness".

The professionals could no longer present an official 
position in the face of the data presented by the organized homosexual community. There were, however, many psychiatrists who still held to some degree the belief in the pathological nature of homosexuality. The idea of "disturbance" in an individual who is faced with societal prejudice coming to a heterosexual psychiatrist, still leaves the way open for approaching homosexuality itself as a problem. After the decision, Dr. Spitzer told reporters, "in no longer considering it a psychiatric disorder, we are not saying that it is normal, or that it is as valuable as heterosexuality". 127

The decision opened a door to the validation of an individual's right to a unique sexual self-definition. Whether practice has significantly changed, either on the professional or para-professional level, is a question which requires continuing study. 
13 Elizabeth Gould Davis, The First Sex (New York: G.P. Putnam's Sons, 1971), Chapter 4.

${ }^{14}$ Arno Karlen, Sexuality and Homosexuality (New York: W.W. Norton \& Co., 1971), P. 6 .

15 Ibid

1.6 Robert Graves, The White Goddess (New York: Farrar, Straus and Giroux, 1948), Chapter 22 .

17 Ibid., Chapter 4.

${ }^{18}$ op. Cit., ref. 1, Part II.

${ }^{19}$ Op. Cit., ref. 2, p. 10

20 Leonard Woolley, A Forgotten Kingdom (London: Penguin, 1954), p. 85 .

${ }^{21}$ Saul H. Fisher, "A Note on Male Homosexuality and the Role of Women in Ancient Greece", in Sexual Inversion: The Multiple Roots of Homosexuality (New York: Basic Books, 1965), pp. 165-1.72.

22 Ibid.

${ }^{23}$ op. Ct., ref. 1, p. 141.

${ }^{24}$ C.A. Tripp, The Homosexual Matrix (New York: McGraw-Hil1, 1975), p. 6 .

\section{Ibid.}

${ }^{26}$ William I. Langer (ed.), An Encyclopedia of World History 4th ed. (Boston: Houghton Mifflin Co., 1968), Chapter II, Section F.

${ }^{27}$ Op. Cit., ref. 2, p. 67. 
${ }^{28}$ Ibid., p. 69.

${ }^{29}$ Mathew, $5: 28$.

${ }^{30}$ op. Cit., ref. 2, p. 71.

${ }^{31}$ op. Cit., ref. 14, Chapter III, Section A.

${ }^{32}$ op. Cit., ref. 2, p. 90.

${ }^{33}$ Ibid. , p. 77.

${ }^{34}$ Op. Cit., ref. 14, p. 136.

${ }^{35}$ Ibid., p. 188

${ }^{36}$ op. Cit., ref. 2, p. 78 .

${ }^{37}$ Arthur Evans, "Witchcraft: The Gay Counterculture, Part 5: The Mass Murder of Women and Gays", in FagRag 13 (Summer, 1975), p. 13

${ }^{38}$ Ibid.

${ }^{39}$ Ibid.

40 Ibid.

${ }^{41}$ op. Cit., ref. 2. p. 69.

${ }^{42}$ op. Cit., ref. 25, p. 14

${ }^{43}$ Ibid. , p. 13.

${ }^{44}$ Ibid.

${ }^{45}$ Ibid. , p. 14

${ }^{46}$ Ibid.

${ }^{47}$ op. Cit., ref. 14, p. 236.

${ }^{48}$ Ibid., pp. 246-248. 
${ }^{49}$ Ibid., p. 313.

50 Op. Cit., ref. 2, p. 97: "A11 witchcraft comes from carnal lust, which in women is insatiable.. But if it be asked why the Devil is allowed to cast spells upon the venereal act... the power of the Devil lies in the privy parts of men".

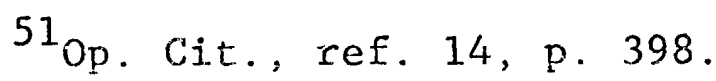

${ }^{52}$ op. Cit., ref. 2, p. 125.

${ }^{53}$ Ibid., p. 126.

${ }^{54}$ Ibid., p. 149 .

55 Ibid., p. 162

${ }^{56}$ Samuel Iissot, L'Onanisme (Lausanne: A Chapuis, 1760). ${ }^{57}$ Op. Cit., ref. 2, p. 185.

58 John Lauritsen \& David Thorstad, The Early Homosexua1 Rights Movement (New York: Times Change Press, 1974), p. 9.

${ }^{59}$ Op. Cit., ref. 2, p. 187.

60 Ibid., p. 188.

${ }^{61}$ Josef Breuer \& Sigmund Freud, Studies in Hysteria (Boston: Beacon Press, n.d.).

${ }^{62}$ op. Cit., ref. 2, p. 258.

${ }^{63}$ op. Cit., ref. 49 .

${ }^{64}$ Sigmund Freud, The Interpretation of Dreams (New York: Modern Library, 1950).

${ }^{65}$ Sigmund Freud, Three Essays on the Theory of Sexuality (New York: Avon, 1965).

${ }^{66}$ It's interesting to note that according to the theory it is natura]. for some iibido to reside in the mouth and the genitals, but unnatiral for any libido to reside in the anus. 
${ }^{67}$ op. Cit., ref. 53 .

${ }^{68}$ Ibid.

${ }^{69}$ Ibid., emphasis added.

${ }^{70}$ Sigmund Freud, "Letter to American Mother", American Journal of Psychiatry, Vo. 107 (1951), pp. 786-787; emphasis added.

${ }^{71}$ op. Cit., ref. 2, p. 261.

72 Sigmund Freud, "The Psychogenesis of a Case of Female Homosexuality", International Journal of Psychoanalysis, I:2 (1920), pp. 133-135.

${ }^{73}$ Ibid., quoted in Gay American History, Jonathan Katz, ed. (New York: Thomas Y. Crowel1 Co., 1976), p. 158.

74 The Body Politic (No. 33, May 1977) reports that James D. Steakley recently discovered four new documents disclosing Freud's attitude on homosexuality. They are: an interview published in Die Zeit (Vienna), October 27, 1903, p. 5, in which Freud says homosexuality is not a sickness or crime, and distinguishes it from child molestation; two letters by Freud and Otto Rank (1921, 1922) rejecting homosexuality per se as sufficient reason to refuse membership in the Psychoanalytic Association; a memorial by Freud to Magnus Hirschfeld in Fur Magnus Hirschfeld Seinem 60. Geburstage, Linsert and Hiller, eds. (Berlin: Wissenschaftlichhumanitares Komitee, 1928), p. 7, in which he advocates legal rights for homosexuals; and "Appeal to the Penal Justice Commission Concerning the Repeal of the Law on Homosexuality", Weiner Arbeiterzeitung (May 16, 1930), which was signed by Freud, among others.

The accompanying article points out several criticisms of Freud, one of which is that his personal opinion did not affect the structure of his theory, which sees homosexuality as a manifestation of incomplete development.

${ }^{75}$ Alfred Adler, Individual Psychology (New York: Harper Torchbook, 1964).

${ }^{76}$ op. Cit., ref. 2, p. 285.

77 Ibid.

${ }^{78}$ Ibid., p. 287. 
${ }^{79}$ Ibid.

${ }^{80}$ Ibid., p. 289.

${ }^{81}$ Sandor Ferenczi, "The Nosology of Male Homoseruality", in Psychoanalysis and Male Sexuality (New Haven: College \& University Press, 1966).

${ }^{82}$ Ibid.

${ }^{83}$ Op. Cit., ref. 2 , pp. 293-295.

${ }^{84}$ Sigmund Freud, The Ego and the Id (New York: W.W. Norton, 1961).

${ }^{85}$ Wilhelm Reich, Character Analysis (New York: Orgone Institute Press, 1949).

${ }^{86}$ Ibid.

87 Wilhelm Reich, The Function of the Orgasm (New York: Simon \& Schuster, 1968).

${ }^{88}$ Helene Deutsch, Psychology of Women (New York: Grune \& Stratton, 1944).

${ }^{89}$ Op. Cit., ref. 2, pp. 295-296.

90 Ibid. 1940).

${ }^{91}$ Eugen Steinach, Sex and Life (New York: Viking Press,

${ }^{92}$ op. Cit., ref. 2 , p. 331.

93 James C. Coleman, Abnormal Psychology and Modern Life, 4th ed. (Glenview, Illinois: Scott, Foresman and Co., 1972), p. 57.

${ }^{94}$ Reader's Digest, September, 1948.

95 New York Times, April 1, 1948.

${ }^{96}$ Ibid., March 7, 1948.

97 Ibid., December 20, 1954. 
${ }^{98}$ Ibid.

99 Jonathan Katz, ed., Gay American History (New York:

Thomas Y. Crowe11 Co., 1976), p. 129.

100 op. Cit., ref. 2, p. 332 .

${ }^{101}$ Ibid.

102 Ibid.

1030p. Cit., ref. 87, p. 144.

${ }^{104}$ op. Cit., ref. 2, p. 333.

105 Ibid., p. 334 .

${ }^{106}$ Op. Cit., ref. 87, p. 153.

${ }^{107}$ Ibid., p. 145.

${ }^{108}$ Ibid., p. 162.

${ }^{109}$ Ibid., p. 167.

110"Aberrations of the Sexual Instinct", Medical Times and Gazette (London), I (Feb. 9, 1867), p. 144.

111 op. Cit., ref. 87, p. 170 .

112 Ibid., p. 201.

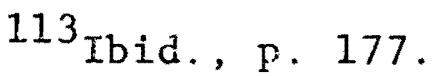

114 Ibid., p. 198.

${ }^{115}$ Ibid.., p. 199.

${ }^{116}$ Irving Bieber, et. alia, Homosexuality: A Psychoanalytic Study of Male Homoserruals (New York: Random House, 1962).

${ }^{117}$ op. Cit., ref. 2, p. 573. Karlen is one of thos who accepts and praises Bieber's findings. Although Karlen's work is an invaluable survey of the history of anti-homosexuality, Karlen himself is blind to the logical consequences of the facts he presents. 
118 Thomas S. Szaz, "The Product Conversion", in The Homosexual Dialectic, Joseph A. McCaffrey, ed, (New Jersey: Prentice-Ha11, 1972), p. 101.

119 Ibid. , p. 107.

120 Karla Jay and Allen Young, eds., Out of the Closets; Voices of Gay Liberation (New York: Dougias, 1972), p, 145 ,

${ }^{121}$ Ibid., p. 147.

12.2 Ibid., p. 144.

123 New York Times, February 10, 1973.

124 Ibid.

125 New York Times, December 16, 1973.

126 Ibid.

127 Ibid. 
CHAPTER IV

\author{
METHODOLOGY
}

\title{
Purpose
}

The attitudes of psychiatrists and psychologists toward homosexuality is well documented in the 1iterature. The purpose of this questionaire is to determine the attitudes about homosexuality of psychiatric nurses and aides at state mental hospitals.

I am assuming, that the pressures of anti-homosexual bjas in society cause many homosexuals to become emotionaliy disturbed. Those who are poor and those who are most severely disturbed will be placed in state mental hospitals. What will they find? How will the employees who are most directly and consistently in contact with the homosexual patients treat them? This depends, to a large extent, on what these employees' personal attitudes are. The answer will have a great effect on whether the homosexual can accept his or her sexuality, and work through the emotional problems in a therapeutic environment.

I atterpted to find out real attitudes by soliciting responses to statements which cover a range of the most favorable inaginable, toward homosexuality, to the least favorable imaginable. I also attempted to include conmon cliches often heard about homosexuals. The statements were developed with a view toward determining the extent of liberalism, the expression of a seemingly 
favorable attitude, which has hidden and unfavorable dimensions. The Questionaire

This is a survey of personal attitudes about homosexuality on the part of psychiatric nurses and aides at state mental. hospitals. Although I had planned to survey all three of Oregon's state hospitals, one was not contacted and refused to participate.

All three hundred nurses and aides at the remaining hospital were given the questionnaires. I brought the questionnaires to the Director of Nursing Services. He game them to the head nurse on each ward, to be distributed to staff at the beginning of each of three shifts. A week was allowed for response. The questionnaires were to be returned individually to the director's office. I picked them up there at the end of the week.

The questionnaire itself consists of three sections (See Appendix A for complete questionaire); Part One is a series of multiple choice questions about personal background. The questions from this part analyzed in the current report are:

What is your age?

Are you female male

What level of schooling have you had?

Marital status?

No question is asked about the respondent's sexual orientation. It was considered possibly intimidating, and was deemed unnecessary for determining attitudes about homosexuality.

Section Two consists of fifteen multiple choice questions. Questions analyzed in this paper are: 
How much of your duties are with patients?

Do you think there are homosexual workers at your facility?

What effect do you believe homosexual workers have on patients?

In your opinjon, do homosexual patients have special problems that other patients don't have?

The questions are designed to give information about the practical effect of homosexuality in the hospital setting, from the respondent's point of view.

Section Three contains the primary test of personal attitudes toward homosexuality. Twenty-six statements of an attitude were presented. Respondents were asked to make one of six responses: strongly agree, agree, tend to agree, tend to disagree, disagree, and strongly disagree.

The statements express attitudes along a spectfum from radical through liberal to conservative, responses to homosexuality, The radical statements express attitudes finding homosexuality (in some cases reversals of common statements against homosexuality) superior in some way. They also involve making a personal choice to accept one's own homosexual desires. The radical statements are not meant to be common attitudes, but one which are the most favorable in view of Kinsey's studies, and the desire of some Gay activists to encourage homosexuals to assert the rightness of homosexuality.

Some also simply represent the most extremely favorable attitude that it's possible to imagine. The radical statements analyzed here are: 
I would like to have a homosexual experience.

Homosexuality is healthier than heterosexuality.

I hope my children become homosexual.

The liberal statements express attitudes which: are noncommittal about homosexuality; sound positive but have an underlying negative dimension; or lead to unfavorable treatment; are abstract and involve no personal consideration or commitment.

These liberal statements often are commonly heard cliches about homosexuality. I expected that the majority of people would agree with these, since they release people both from responsibly and personally addressing homosexuality on the one hand, and from being guilty of narrowminded and unreasonable beliefs on the other. The liberal statements analyzed here are:

People shouldn't be labeled by their sexuality. Homosexuals are no problem as long as they don't flaunt it.

The conservative statements express beliefs that homosexuals are strange and different; that they need to be suppressed; that homosexuality is inferior to heterosexuality; that homosexuals have a repulsive manner which may influence children to turn into homoseruals. These are the beliefs of the past, which still are expressed in our laws, religious beliefs, psychiatric practice, and the attitudes of many people. Though some progress has been made away from this, most people still refuse to validate homosexuality in others, and homosexual feelings in themselves. Conservative statements analyzed here are"

Homosexuals should be put into jail.

Homosexuality is unnatural 
The two variables, type of attitude and degree of response, can be used to pinpoint a general attitude.

A page of explanation was included with each questionnaire (See Appendix B). It explained who was being surveyed, the purposes of the survey (to fulfill my degree requirement in Social Work, and to be used by the Governor's Task Force on Sexual Preference). It explained that cooperation is voluntary; that no personal or agency identification will be made. It asked respondents not to sign it, refrain from discussing it, and complete it as quickly and completely as possible.

Data Analysis

The present report uses a number of questions from each section, which were considered significant or representative of the other questions the respondents answered. The full range of possibilities inherent in the replies will be examined at a later time. This paper is the report of preliminary findings. In Part One I chose to use the questions relating to age, sex, schooling, and marital status. Age was chosen because of an assumed liberalizing trend in recent years, which may affect younger people. Homosexuality, and sexuality in general, is more open for discussion now. There is a commonly held belief that younger people are more open minded about sexuality than they have been in the past. For these reasons, I am looking for differences in attitude between younger and older people.

Unfortunately, the questionnaire doesen't clarify whether the respondents feel homosexuality is a phenomenon of one sex or the other. As we have seen, the literature has talked about it most often in relation to men. I chose sex as a characteristic 
to analyze because men and women experience sexuality somewhat differentiy, and because there seems to be more focus on male sexuality; witness the greater show of gay male bars, male cross-dressing, and effeminate mannerisms. I expected women to be somewhat less threatened by homosexuality (if seen in this male image) than men.

One of the goals of education is to promote understanding and open mindedness. An educated person has more exposure to information and opposing argument. If these things are true, I felt that education may reveal differences in respondents' openness to homosexuality.

While some homosexuals are also married, marriage presumably limits one's sexual activities with anyone but the spouse. Heterosexual activity is supposedly less considered, so homosexuality would be also. Someone experiencing a successful marriage might be less open to validating other sexual arrangements, especially homosexuality. To determine whether these assumptions are true, I chose marital status as a variable to be tested against attitude.

For this analysis, I chose those questions from Section Two which seemed to me to have the most direct effect on treatment of homosexua1 patients.

I wanted to know how much time the respondent spends with patients. Obviously this indicates how much personal effect their attitude will have. I also wanted to see if there was any relationship between an attitude, and whether there were homosexuals among their fellow workers. Belief that there are 
homosexuals among them may be threatening, and predispose a negative attitude, or instructive, and predispose a positive attitude. Leading from this I chose to look at how the sample replied to the question of what kind of effect homosexual workers have on pacients. I wanted to see if there were any inconsistencies between this and response to the attitude statements. Finally, I asked if the respondents felt homosexuals, as patients, had special problems. Once again I wanted to check for consistency with the attitude statements. This would help to determine if personal attitude affects opinion about practical treatment.

The seven questions from Section Three were chosen as representative of the radical, liberal, conservative continuun. Two of the radical statements used express a:strong personal advocacy of homosexuality for oneself, and one's children. The third is a more general statement which is extremely pro-homosexual, to the point of finding it superior.

of the liberal statements chosen, both are commonly expressed beliefs. The statement on labeling sounds openminded and fair. It fails to recognize, however, that homosexuals are usually labeled and treated differently. The practical effect of the statement is that homosexuals must hide as they always had in our society. It has been argued that anti-homosexuality will not change unless homosexuals identify themselves and assert their right to chosen sexual orientation. The second statement is a common liberal attitude which says that the person can accept those who are different, as long as they act the same.

Those statements which are conservative are clearly antihomosexual. They also represent the basis for the legal, relious, 
and psychiatric treatment of homosexuals. One gives nature itself as justification that homosexuality is bad. The other advocates that this bad influence be removed from society and heavily controlled. Thus, these questions represent the full range of all the questions on the questionnaire, including radical, liberal, and conservative responses.

The Pre-Test

Before the actual survey was conducted the questionnaire was administered to staff at four private and public mental health centers in the Portland area. It was explained that their replies would not be used as part of the published data. I requested comments and criticism of the questionnaire. My purpose was to determine the practical possibility of administering the questionnaire, and elicit comments about the questions themselves. Ten questionnaires were filled out and returned.

Resporises were generally favorable and showed an awareness of factual data on sexuality. The pre-test responses looked as if those surveyed felt constrained by the multiple choice format. Severai people wrote in explanations and qualifications of their responses.

Two people felt that the questionnaire demonstrated a bias against homosexuality. They did not explain this. I surmise that this was a reaction to the conservative statements.

The comnents and criticisms of the pre-test were examined and appropriate changes were made in the final survey. Sample and Return Rate

My original target was all the nurses and aides at Oregon's 
three state mental hospitals. One hospital refused to allow the survey. One concern voiced was that it would involve too much staff time.

Other concerns were that repondents might be identified through records based on the background information. It was also objected to that homosexuality was singled out. Additionally there was concern that publicity from the published data may be used adversely.

The first objection can be answered by pointing out that the questionnaire is relatively short. It required almost no written replies. Apparently the time involved was not a problem at the hospital which permitted the survey.

Since this is a controversial area, the hospital was worried about how the data would be used. It is possible that it can be misused, but I think this is true of any survey. I felt the mistrust shown was unnecessary. My purpose is to provide reliable data in an area where we have little knowledge. I assume that information will benefit both those receiving and those administering mental health care. I have no intention of embarrassing, or identifying, indiviuals or agencies.

The third hospital was not contacted because of limitations on time and money. This is also the reason only a portion of the survey is analyzed here. I intend to complete the full survey at a future date.

Three hundred questionnaires were administered. I received a very poor return rate of twenty-five percent. For this reason, and because it represents only one hospital, the sample analyzed 
cannot give reliable information about attitudes of nurses and aides in general. This, then, is a report of perliminary findings, represerting only the small sample studies. Probably those who didn't respond were uneasy about the survey. This is a controversial subject. Homosexuals are not legally protected in Oregon, and perhaps some homosexual. workers feared loss of status and employment.

Many people probably felt sexuality is a private matter, and did not want to disclose information. Some probably did not want to rock the boat, and felt it best to leave the entire matter alone.

There are always limitations on using a questionnaire versus interviewing. There is less pressure to comply. Additionally, the fact that is was administered through the hospital staff probably aroused people's suspicions.

The questionnaire does, I think, address real, widespread attitudes. Also, I was heartened to find that thos who did respond had a variety of personal characteristics.

The age range of the respondents was spread rather evenly, slightly greater in early middle age.

Forty-one of the respondents were male. Thirty-two were female. This is a lower ratio of women than in the population in general.

Though this may reflect some unknown relationship to responding about this issue on the part of women, it might just be that it refiects a greaced number of males employed at the hospital. 
TABLE I

CHARACTERISTICS OF THE SAMPLE

Sample: $N=75$

\begin{tabular}{|c|c|c|c|}
\hline Age: & $\begin{array}{l}\text { Under } 21 \\
20 \text { 's } \\
30 \text { 's } \\
40 \text { s s } \\
50 \text { s s } \\
60 \text { 's }\end{array}$ & $\begin{array}{l}5 \% \\
32 \% \\
26.6 \% \\
14.6 \% \\
16 \% \\
5 \%\end{array}$ & 、 \\
\hline Sex: & $\begin{array}{l}\text { Female } \\
\text { Male }\end{array}$ & $\begin{array}{l}42.6 \% \\
54.6 \%\end{array}$ & \\
\hline \multicolumn{4}{|c|}{ Education: } \\
\hline Mari & $\begin{array}{l}\text { tal Status } \\
\text { Currently } \\
\text { Currently }\end{array}$ & $\begin{array}{l}\text { ingle } \\
\text { arried }\end{array}$ & $\begin{array}{l}42.6 \% \\
53.3 \%\end{array}$ \\
\hline Do $y$ & $\begin{array}{l}\text { ou work wi. } \\
\text { NO } \\
\text { YES }\end{array}$ & $\begin{array}{l}\text { Patients? } \\
12 \% \\
85.3 \%\end{array}$ & \\
\hline
\end{tabular}


Eighty-five percent of the respondents had attended at least some college. Once again, it is uncertain whether this is an accurate representation of the whole staff, or a relationship to responding to the questions. The data reflects a range of attitude within this educated group.

Forty respondents are currently married and thirty-two are currently single. A large eighty-five percent do most of their work with patients. The spread along sex, age, and marital status was good, with large numbers in most categories.

Two questions which sought opinions relating to the prescense of homosexuals at their hospital brought interesting results. When asked if there were homosexual workers there, fifty-seven percent felt that there were, forty percent didn't know, and only two-and one/half percent said no, there were no homosexual workers.

Forty-five percent felt that homosexual workers have no effect on patients, and forty percent didn't know. Twelve no percent thought they have a bad effect, and a very small onepoint-three percent felt that they have a good effect.

\section{Expectations}

The third section consists of statement expressing attitudes about homosexuality. The statements are designed to express radical, liberal, and conservative attitudes. Response to each question can vary from strongly agree, to strongly disagree. A response to a statement can be examined for the degree to which one agrees or disagrees. This is analyzed in relation to the type of statement it is. 
Some issues underlying the statements are whether homosexuality should be seen in a special sense; which sexual preference is better, if any; whether homosexuality is right or wrong, and should be dealt with or not; the relationship of homosexuality to children; and the practical effect of homosexuality on one's own life. Some of the statements are general, others more personal.

As indicated in Chapters II and III, the overall attitude of society has long been anti-homosexual. I expect, then, that the data will show a negative tendency. There should be some tendency toward liberalism, however. Kinsey's studies indicate that many people share somehomosexual feelings, although they don't necessarily identify them as such. Also, the increasing impact of homosexual organizations, and the recent modification of official attitudes should have a liberalizing effect.

I also expect that most people will not take strong stands. I expect respondents will give more negative responses to questions which relate to their own personal sexual orientation, and to those close to them. I expect that most people will take a stronger stand on more moderate attitudes, a moderate stand on stronger attitudes, and a strongly negative stand on extreme attitudes. 


\section{CHAPTER V}

\section{FINDINGS}

The statements examined here represent several larger issues. Which sexual preference is desirable? To what extent i.s another sexual preference accepted? What, if anything, should be done about homosexuality? The relationship of homosexuality to one's own life. The relationship of homosexuality to children.

Some of the statements express general opinions about homosexuality. Others express a more personal attitude about its effect on one's own life.

I expect that the responses will show an overall conservative tenciency. There will also be an acceptance of liberalism, however. Feople generally will refrain from taking strong stands. They will respond more strongly to liberal statements, less strongly to more extreme statements, and negatively to the most extreme statements.

First, I will present the overall response to the statements. These will be presented in groupings, along the radical, liberal, conservative spectrum. I will then compare responses with personal characteristics, using $\mathrm{ch}^{2}$ tests. 
TABLE II

RESPONSE RATE TO RADICAL STATEMENTS

\begin{tabular}{|c|c|c|c|c|c|c|}
\hline \multirow{3}{*}{$\begin{array}{l}\text { STATEMENTS } \\
\text { "I would like to } \\
\text { have a homosexual } \\
\text { experience" }\end{array}$} & \multicolumn{6}{|c|}{ RESPONSES } \\
\hline & $\begin{array}{l}\text { Strong- } \\
\text { ly } \\
\text { Agree } \\
\end{array}$ & Agree & $\begin{array}{l}\text { Tend } \\
\text { to } \\
\text { Agree }\end{array}$ & $\begin{array}{l}\text { Tend } \\
\text { to Dis- } \\
\text { Agree } \\
\end{array}$ & $\begin{array}{l}\text { Dis- } \\
\text { Agree }\end{array}$ & $\begin{array}{l}\text { Strong- } \\
\text { ly } \\
\text { Agree } \\
\end{array}$ \\
\hline & 0 & 4 & 0 & 6 & 14 & 47 \\
\hline $\begin{array}{l}\text { "I hope my } \\
\text { children become } \\
\text { homosexual" }\end{array}$ & 0 & 1 & 0 & 6 & 14 & 50 \\
\hline $\begin{array}{l}\text { "Homosexuality is } \\
\text { healthier than } \\
\text { heterosexuality" }\end{array}$ & 0 & 0 & 0 & 11 & 20 & 37 \\
\hline
\end{tabular}


These statements represent the most favorable toward homosexuality. I expected the most negative response on these, which is borne out by the results. The negative reaction reflects the anti-homosersual ideology still common in society.

"Homosexuality is healthier than heterosexuality" is one of the "most extreme imaginable" statements. I assume that one would be hard pressed to find a heterosexual who agrees with this. I also think that few homosexuals would say this, although heterosexuals say the reverse about them. Although no one agreed at all, there appears to be slightly less extreme disagreement than with the other two radical questions. This is possible because the statement is a more general question, and a position is taken with fewer personal implications.

The response rates to the other two radical questions are almost identical. These demonstrate the weight of disagreement with statements which imply a strong personal openness to homosexuality. This seems to contradict Kinsey's findings that many people are open to homosexual experience. There axe several explanation for this.

There may have been some suspicions about revealing too much. Also, as Kinsey pointed out, the questionnaire format is not the best one for eliciting honest information. It may also be that this sample is not an accurate sample of society at large.

It's interesting to note the slight difference between these two statements' response rates. While four people expressed the desire for a homosexual experience, only one person wanted 
their children to be homosexual. (This may have been a mistaken reading, since this person was not one of the four on the other question). This shows the degree to which even sympathetic people find homosexuality undesirable in relation to children. In general, these responses show a great reluctance to afford homosexuality on equal validity to heterosexuality.

I expected responses to the liberal statements would show strong agreement. The data was, therefore, somewhat unexpected. Although majorities leaned to the "agree" side, there was not overwhelming consensus.

As expected, most people agreed with the statement, "People shouldn't be labeled by their sexuality". The majority of the sample are liberal. They agree with a general statement, which. seems operininded. They were less strongly liberal than I expected, but the response is significant when compared to the majorities on other questions. To make some of the other responses, many respondents had to contradict this expressed believe that people (presumably including homosexuals) shouldn't be labeled. Liberalism often is a result of a lack of serious consideration and of a commitment to a consistent attitude. I think comparison with responses to other statements shows this characteristic in the sample.

The other liberal questions apparently didn't tap the liberal dimension. Although a slight plurality favored "tend to agree", the response is rather evenly spread. It's possible that the statement is too familiar, and people were wary of its implications. Perhaps, as respondents, the pre-test commented, it 
was confusing because it expressed two different attitudes.

The responses to the liberal questions do indicate liberalism in a majority of the sample. However, the majority is not a large one, and the liberalism is not strong. Many respondents have either radical, conservative, or very inconsistent attitudes. To determine this, we must look to the responses to other statements. As we have seen a large majority do not have radical attitudes.

I expected that many people would find jailing homosexuals too strong. I did not expect that there could be such a clear majority strongly against it. The sample is not strongly conservative in their attitudes about dealing with homosexuals. This is confusing since most respondents are not clearly radical nor conservative either.

Response to keeping homosexuals from children did not demonstrate any clear attitude preference. Respondents were distributed rather equally among all choices. This is an attitude which is often expressed in opposition to homosexuality. Attitudes may have been this dispersed because people lack information on the prevalence of homosexuality among child molesters, and on the development of sexual preference in children. Most studies indicate that child molesters are rarely homosexuai. 
TABLE III

RESPONSE RATES TO LIBERAL STATEMENTS

STATEMENTS

RESPONSES

Strong- Tend Tend Strong-

$1 y$

to

to Dis- Dis-

$1 \mathrm{y}$

Agree

Agree

Agree

Agree

Agree Agree

"People shouldn't

be labeled by their sexuality"

29

18

10

5

4

5

"Homosexuals are no problem as long as they don't flaunt it"

17

22

10

7

9 
TABLE IV

RESPONSE RATES TO CONSERVATIVE STATEMENTS

STATEMENTS

Homosexuals should be put in jail"

"Homosexuals should be kept away from children"
14
RESPONSES

\begin{tabular}{llll} 
Strong- & Tend & Tend & Strong- \\
ly & to & to Dis- Dis- & 1y \\
Agree & Agree & Agree & Agree Agree Agree \\
\hline
\end{tabular}

0

1

1

8

20

41 
TABLE V

AGE AND THE RADICAL STATEMENTS

"I would like to have a homosexual experience"

ACE :

20 's \& Uncer

$30^{\prime} \leqslant \& 40^{\prime} s$

$50^{\prime} \mathrm{s} \& 60^{\prime} \mathrm{s}$

\begin{tabular}{|c|c|}
\hline AGREE & DISAGREE \\
\hline $1.5 / 1$ & $25 / 26$ \\
\hline $1.7 / 3$ & $27 / 26$ \\
\hline $.8 / 0$ & $13.2 / 14$ \\
\hline 4 & 66 \\
\hline
\end{tabular}

$x^{2}=1.78$, ns @ $2 \mathrm{df}$

n.r. $=5$
n. $=75$

"I hope my children become homosexual"

$A G E$ :

20's \& Under

\begin{tabular}{|c|c|c}
\hline AGREE & \multicolumn{1}{c|}{ DISAGREE } \\
$.37 / 0$ & $25.6 / 26$ & 26 \\
$.4 / 1$ & $29.6 / 29$ & 30 \\
$.21 / 0$ & $14.8 / 15$ & 15 \\
\hline 1 & 70 & 71
\end{tabular}

$x^{2}=1.26$, ns c 2 df

n.r. $=4$
n. $=75$ 
These responses show a great deal of variability, and do not indicate clear attitude patterns. There is no large majority in any of my three scales of attitude. Next I look at the relationship of personal characteristics.

$$
\frac{\text { PERSONAL CHARACTERISTICS OF }}{\text { THE SAMPLE AND ATTITUDES }}
$$

Age

I did a series of $\mathrm{chi}^{2}$ tests to determine if there were significant relationships between personal characteristics and attitude. Since there was no agreement "Homosexuality is better than heterosexuality", this statement's responses will not be examined. First we'11 look at the radical statements and age. (See Table V).

Age does not prove to be a significant variable with regard to opinion about the radical statements. The distribution is close to random in both examples.

In the first example, a slightly higher number of respondents in the age 30 to 40 group agxeed. This is not a significantly large increase however. One may conjecture that younger people may be more open to homosexuality, or conversely, more threatened by it. These dynamics did not appear among the sample in response to the radical statements. All age groups are remarkable similar in their rejection of the radical statements.

Next we'l1 see if age is a factor in differing responses to liberal statements. 
TABLE VI

AGE AND LIBERAL STATEMENTS

"People shouldn't be labeled by their sexuality"

AGE :

$20^{\prime} \mathrm{s} \&$ Under

AGREE

DISAGREE

$30^{\prime} s \& 40^{\prime} s$

\begin{tabular}{|c|c|}
\hline $22 / 23$ & $5.5 / 5$ \\
$24 / 25$ & $5.9 / 5$ \\
$10.9 / 9$ & $2.6 / 4$ \\
\hline 57 & 14 \\
\hline
\end{tabular}

28

30

$50^{\prime} \mathrm{s} \& 60^{\prime} \mathrm{s}$

14

13

71

$\mathrm{x}^{2}=1.21, \mathrm{~ns}$ @ 2. df

n.r. $=4$

n. $=75$

"Homosexuals are all right, as long as they don't flaunt it"

AGE :

$20^{\prime}$ s \& Under

AGREE

DISAGREE

$30^{\prime} 2 \& 40^{\prime} \mathrm{s}$

$9.6 / 9$

$16 / 17$

26

$50^{\prime} s \& 60^{\prime} s$

$10.7 / 9$

$18.2 / 20$

29

15

26

$9.4 / 7$

44

70

$\mathrm{x}^{2}=2.19, \mathrm{~ns} @ 2 \mathrm{df}$

n.r. $=5$
n. $=75$ 
Age did not prove to be a significant variable for the overal]. sample on these two liberal statements. Those under 50 years of age did not differ significantly in their agreement with liberal statements.

There was slightly more disagreement with the statement on labeling among the over 50 years of age group. This may suggest that their exposure to the more anti-homosexual attitudes of the past, is a factor in making them less liberal toward homosexuals. While the other age groups were close to ramdom in their response to the statement about flaunting, the over 50 group demonstrated more agreement, and less disagreement, than random. This does not demonstrate a clear attitude. Since there are such few people in the over 50 category, no clear relationship can be shown. The data demonstrates no clear relationship between age and response to liberal questions.

Next we'11 look for a relationship between age and response to conservative statements (See Table VII).

There were no significant differences among age groups in their response to the statement advocating jailing of homosexuals. This was clearly too extreme a measure for most people. Since state mental hospitals are sometimes an alternative to jajl, this may indicate a relationship to the fact that the sample is drawn from workers at this facility.

The second statement, which has been traditionally used by mental health care professionals, demonstrated a significant deviation from what might be randomly expected, while the group in the 30 to 40 age group were divided almost equally in their response. Significant differences were shown in the younger and 
AGE AND CONSERVATIVE STATEMENTS

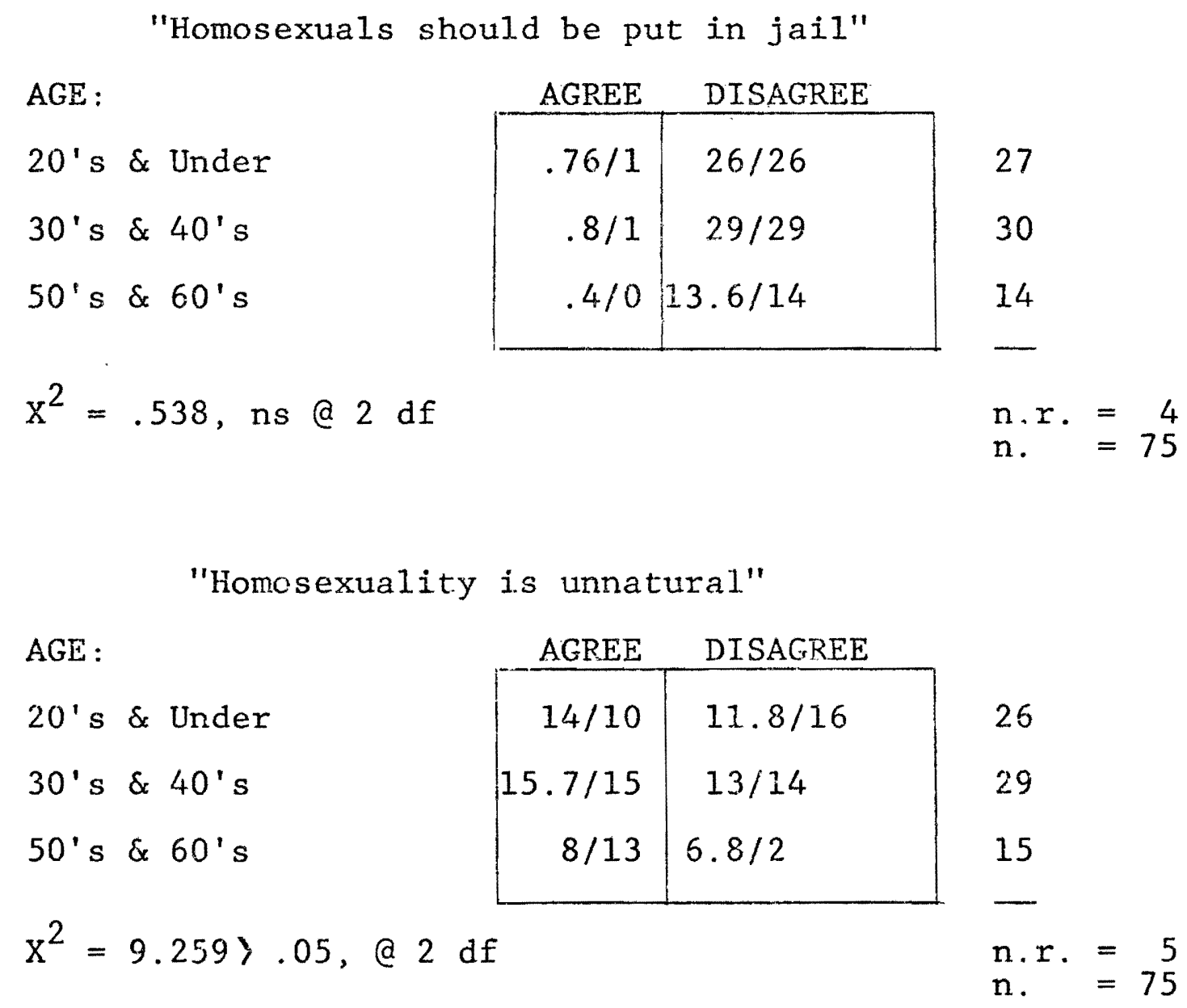


and oldest of the three groups.

Younger people rejected the notion that homosexuality is unnatural, to a significant degree, while older people agreed with it to a significant degree.

The numbers involved in this sample are small. Generalizations, even about the sample tested, must be guarded. This response did elicit a significant variation, however. It is interesting that the sample showed a difference among age groups, in response to an attitude which has been used to justify treatment of homosexuals within mental health institutions.

With caution, we might say that younger people don't believe in the unnaturalness of homosexuality. It may be that in this area, at least, of the origin of homosexuality, modern evidence has had an instructional effect on young people.

Conversely, it seems that the oldest members of the group have held on to the belief to which they undoubetedly had much exposure in the past.

Marital Status

This category is expected to be significant because of the variation in heterosexual experience, and the possible variation in limitations on sexual interest. Another factor which may be present is the extent to which non=heterosexual arrangements are seen as valid.

In relation to the radical statements, marital status does not prove to be a significant variable. With both of the statements, both groups are close to random in their overwhelming rejection of radical attitudes. Marital status will now be 
TABLE VIII

MARITAL STATUS AND RADICAL STATEMENTS

"I would like to have a homosexual experience"

\begin{tabular}{|c|c|c|}
\hline & AGREE & DISAGREE \\
\hline Currently Single & $1.8 / 3$ & $28 / 27$ \\
\hline Currently Married & $.6 / 1$ & $35 / 36$ \\
\hline
\end{tabular}

n.r. $=8$

n. $=75$

"I hope my children become homosexual"

Currently Single

Currently Married

\begin{tabular}{|c|c|}
\hline AGREE & DISAGREE \\
\hline $.4 / 0$ & $30 / 30$ \\
$.5 / 1$ & $37 / 37$ \\
\hline 1
\end{tabular}

30

$\frac{38}{68}$

$\mathrm{x}^{2}=9, \mathrm{~ns}$ @ $1 \mathrm{df}$

n.r. $=7$

n. $=75$ 
examined in relation to the liberal statements. (See Table IX.)

Marital status showed no statistical significance in

response to liberal statements. In this case, however, $\mathrm{chi}^{2}$ approached a significant level. With both statements a similar pattern emerged. Single people showed a slightly more than random agreement with liberalism, while married people showed slightly more disagreement than normally expected. While this is too slight a difference to generalize from, it shows some tendency toward less liberalism on the part of married members of the sample.

Finally, marital status will be examined in relation to conservative statements, to see if it is a significant factor in the responses. (See Table X.)

Once again, marital status does not appear to be a significant variable in relation to attitude. With the conservative statements the patterns for both groups was fairly consistent. The only variation was slightly more agreement with the statement on unnaturalness. Viewing this with the slightly more pronounced rejection of liberalism by those married, we can see a tendency toward conservatism in the married group.

It is interesting this statement also elicted more conservative in the older. One may see a connection between a more stable lifestyle, and belief that homosexuality is unnatural. $\underline{\text { Education }}$

This category is expected to be significant because of the supposedly greater access to information and opinion. Here we're seeing if there is a greater open mindedness on the part 
TABLE, IX

MARITAL STATUS AND LIBERAL STATEMENTS

"People shouldn't be labeled by their sexuality"

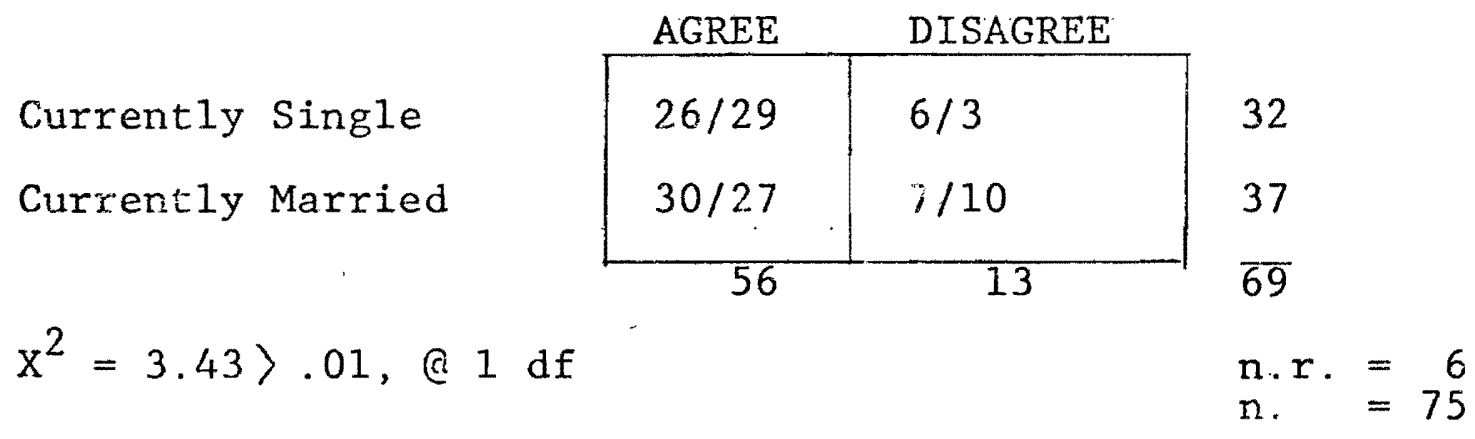

"Homosexuals are no problem as long as they don't flaunt it"

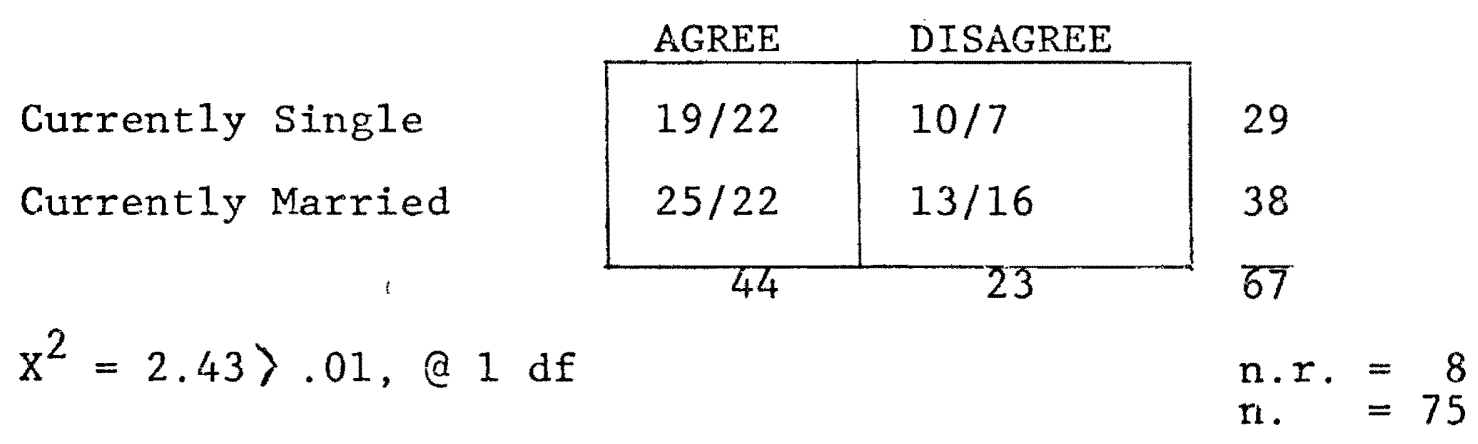


TABLE X

MARITAL STATUS AND CONSERVATIVE STATEMENTS

"Homosexuals should be put in jail"

Currently Single

\begin{tabular}{|r|r|r}
\multicolumn{1}{|r|}{ AGREE } & DISAGREE \\
\cline { 1 - 2 } $.5 / 1$ & $30.5 / 30$ & 31 \\
$.5 / 0$ & $37 / 37$ & 37 \\
\hline 1 & 68
\end{tabular}

$\mathrm{x}^{2}=1$, ns @ $1 \mathrm{df}$
n.r. $=7$
n. $=75$

"Homosexuality is unnatural"

Currently Single

Currently Married

\begin{tabular}{|r|r|}
\hline AGREE & DISAGREE \\
\hline $16 / 14$ & $13 / 15$ \\
$20 / 22$ & $17 / 15$ \\
\hline 36 & 30 \\
\hline
\end{tabular}

29

37

66

$x^{2}=99$, ns C $1 \mathrm{df}$
n.r. $=9$
n. $=75$ 
of educated people. (See Table XI.)

Once again, no significance was found in relation to the radical statements. As with the other categories mentioned, education had no effect on response. With both groups there was overwhelming rejection of the radical statements. The configurations were similar for both groups.

We'11 examine response to liberal statements, to see if education made a significant difference. (See Table XII.)

The configuration of responses were very close to random on the liberal questions. Amount of education apparently has little effect on creation of liberal attitudes. Both groups showed a slight majority, agreeing with liberal attitudes in the sample.

So far education has had little significance to radical or liberal attitudes. The final examination will be of responses to conservative statements. (See Table XIII.)

Although there are differences in response to the two conservative statements, the pattern of the two groups is not significantly different. Both rejected jailing, and were divided, tending to agree, on homosexuality being unnatural.

Over all, marital status is not shown to be very significant in determining the attitudes of the sample.

$\underline{\text { Sex }}$

The sex of the respondents was expected to be significant. Differences in response to sexuality on the part of men and women, may influence how homosexuality is seen. Also there may be a tendency to think of homosexuality as a male phenomenon. 
TABLE XI

EDUCATION AND RADICAL STATEMENTS

"I would like to have a homosexual experience"

\begin{tabular}{|c|c|c|c|}
\hline & AGREE & DISAGREE & \\
\hline No College & $.6 / 0$ & $9 / 10$ & 10 \\
\hline College \& Over & $4 / 4$ & $56.5 / 56$ & 60 \\
\hline & 4 & 66 & $\overline{70}$ \\
\hline
\end{tabular}

"I hope my children become homosexual"

No College

College \& Over

$\mathrm{x}^{2}=.715, \mathrm{~ns}$ @ $1 \mathrm{df}$

\begin{tabular}{|l|l|l} 
AGREE & DISAGREE \\
$.1 / 0$ & $9.9 / 10$ \\
$.9 / 1$ & $59 / 59$ & 10 \\
60 \\
70
\end{tabular}

n.r. $=5$

n. $=75$ 
TABLE XIT

EDUCATION AND LIBERAL STATEMENTS

"People shouldn't be labeled by their sexuality"

No College

College \& Over

\begin{tabular}{|c|c|}
\hline \multicolumn{1}{c|}{ AGREE } & \multicolumn{1}{c}{ DISAGREE } \\
\hline $\begin{array}{c}7.9 / 8 \\
47 / 47\end{array}$ & \begin{tabular}{c}
$2 / 2$ \\
$12 / 12$ \\
\hline 55
\end{tabular} \\
\hline
\end{tabular}

10

59

69

$x^{2}=.0013$, ns a 1 df

n.x. $=6$

"Homosexuals are no problem as long
as they don't flaunt it"

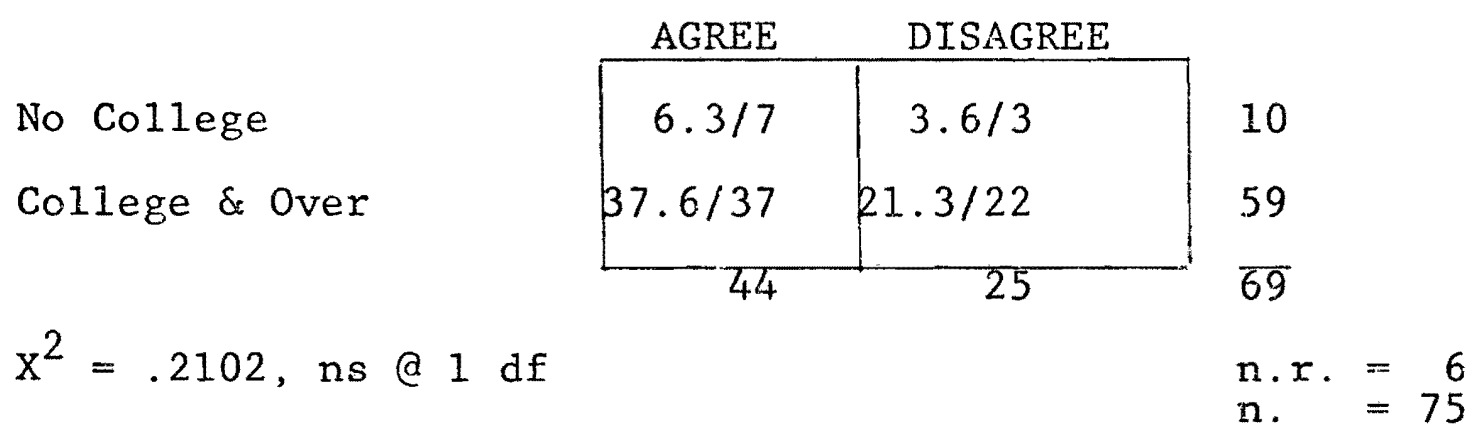


TABLE XIII

EDUCATION AND CONSERVATIVE STATEMENTS

"Homosexuals should be put in jail"

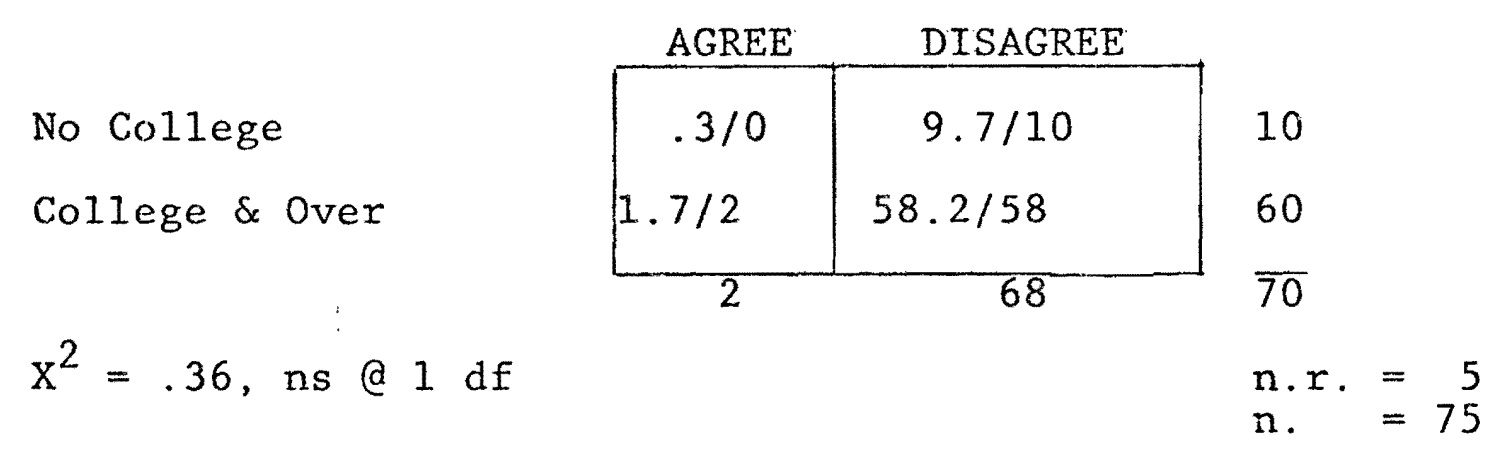

"Homosexuality is unnatural"

No College

College \& Over

\begin{tabular}{|c|c|}
\hline AGREE & DISAGREE \\
\hline $5.4 / 7$ & $4.5 / 3$ \\
\hline $31.5 / 30$ & $26 / 28$ \\
\hline
\end{tabular}

$\mathrm{x}^{2}=1.2$, ns e $1 \mathrm{df}$

n.r. $=7$
n. $=75$ 
In this case, the sex of the respondent might also be of significance. First we'1l examine the response to the radical questions. (See Table XIV.)

As with the other characteristics, sex did not prove to be significant in relation to response to the radical statements. The sample overwhelmingly rejected the radical proposals, and did so regardless of what personal characteristics they were grouped under.

Now we'11 examine whether there were significant differences in response between then and women, to liberal statements. (See Table XV.)

There was no significance in response to the liberal statements by men and women. Apparently, at least with this sample, a person's sex has little influence in their acceptance of liberalism.

The final test of significance will compare sex and the conservative statements. As we have seen, sex has not been shown to be significant in response to the radical and liberal statements. (See Table XVI.) 
TABLE XIV

\section{SEX AND RADICAL STATEMENTS}

"I would like to have a homosexual experience"

Female

Male

\begin{tabular}{|c|c|}
\hline AGREE & DISAGREE \\
\hline $3 / 2$ & $28 / 28$ \\
\hline $2 / 2$ & $36.7 / 37$ \\
\hline
\end{tabular}

$\mathrm{x}^{2}=.34, \mathrm{~ns}$ @ $1 \mathrm{df}$

$$
\begin{aligned}
& \text { n.r. }=6 \\
& \text { n. }=75
\end{aligned}
$$

"I hope my children become homosexual"

Female

Male

$\mathrm{x}^{2}=1.44, \mathrm{~ns} @ 1 \mathrm{df}$

\begin{tabular}{|c|r|}
\hline AGREE & DISAGREE \\
$.4 / 1$ & $30.5 / 30$ \\
$.5 / 0$ & $37 / 38$ \\
\hline 1 & 68 \\
\hline
\end{tabular}

31

38

$\overline{69}$
n.r. $=6$
n. $=75$ 


\section{TABLE XV}

\section{SEX AND LIBERAL STATEMENTS}

"People shouldn't be labeled by their sexuality"

Female

\begin{tabular}{|c|c|}
\hline AGREE & DISAGREE \\
\hline $23.9 / 24$ & $6 / 6$ \\
\hline $31 / 31$ & $7.9 / 9$ \\
\hline
\end{tabular}

$\mathrm{x}^{2}=.0005, \mathrm{~ns}$ @ $1 \mathrm{df}$

$\mathrm{n} \cdot \mathrm{r} .=6$

n. $=75$

\section{"Homosexuals are no problem as long as they don't flaunt it"}

Female

Male

\begin{tabular}{|c|c|c}
\multicolumn{1}{l|}{ AGREE } & DISAGREE & \\
$18.5 / 19$ & $11.4 / 11$ & 30 \\
$23.4 / 23$ & $14.5 / 15$ & 38 \\
\hline 42 & 26 & 68
\end{tabular}

$\mathrm{x}^{2}=.036, \mathrm{~ns}$ @ $1 \mathrm{df}$

n.r. $=7$ 


\section{TABLE XVI}

SEX AND CONSERVATIVE STATEMENTS

"Homosexuals should be put in jail"

Female

Male

\begin{tabular}{|c|c|}
\hline AGREE & DISAGREE \\
\hline $.9 / 0$ & $30.1 / 31$ \\
\hline $1.1 / 2$ & $36.9 / 36$ \\
\hline
\end{tabular}

$\mathrm{x}^{2}=.019, \mathrm{~ns}$ @ $1 \mathrm{df}$

n.r. $=6$
n. $=75$

"Homosexual is unnatural"

Female

\begin{tabular}{|c|c|}
\hline AGREE & DISAGREE \\
\hline $16.4 / 22$ & $13.6 / 8$ \\
\hline $19.6 / 14$ & $16.4 / 22$ \\
\hline
\end{tabular}

$\mathrm{x}^{2}=7.73 \quad .05$, @ $1 \mathrm{df}$

$\begin{array}{ll}\text { n.r. } & =9 \\ \text { n. } & =75\end{array}$ 
Conclusion

No clear attitude tendancies emerged from the findings. The responses did not fall along one of the three attitude dimensions.

Tests demonstrated significance in only a few cases. The causes for these are difficult to determine from the data. Whether the difficulty lies in the small response rate, limited universe or method of survey, is not clear.

This is a sensitive area for most people. Further research, perhaps using more sophisticated methods is necessary. 


\section{CHAPTER VI}

\section{SUMMARY}

In this paper I attempted to gauge attitudes about homosexuality. I applied this to attitudes of those responsible for the care of troubled homosexuals in a mental hospital.

The institution of mental health has long been applied to homosexuality. I attempted to show how this developed historically, demonstrating the social forces at work. I use this as a background against which to examine current attitudes.

The success of this endeavor was limited by the difficulty in engaging a large sample population, and the poor response rate.

The data was inconclusive. No clear generalizations can be made about attitudes or behavior from the data. Likewise, the interaction of historically conditioned social ideology with current popular attitudes can not be determined.

Homosexuality has only recently emerged as a phenomenon for study. There are many aspects which remain undiscovered. This ignorance effects the lives of those served by our social institutions. Attitudes of mental health workers is but one example, although an important one. The social work profession needs to educate itself to the reality of those among the people it serves who are homosexual. 


\section{APPENDIX A}

Questionnaire for Mental Health Workers

On Homosexuality

Part One: Background Information

1. What is your age?

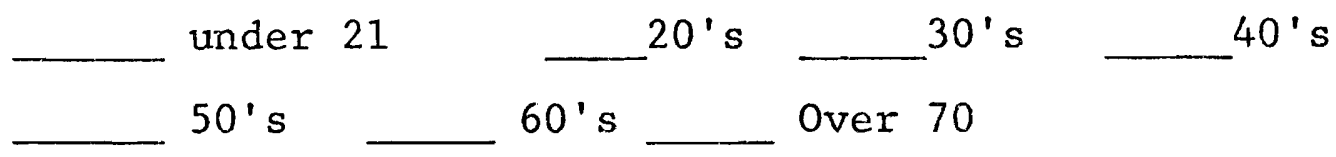

2. Are you female __ male

3. Race?

Black
Mexican-American Asian-American $\quad$ American Induan __ Other:

4. What level of schooling have you had ? (highest leve1)
a. grade school
b. some high school
e. some college
c. highschool diploma $g$.
f. college degree
d. technical school graduate or professional

5. Marital Status?

single
living with lover/unmarried
married
divorced separated widow/widower

6. What is your job title?

7. Yearly income?

Under $\$ 5,000$

$\$ 5,000$ to $\$ 9,999$
$\$ 10,000$ to $\$ 14,999$

$\$ 15,000$ to $\$ 19,999$ Over $\$ 20,000$

8. How long have you worked at your agency? 


\section{Part Two: Your Agency}

1. How much of your duties are with patients?

\begin{tabular}{rr}
$0-25 \%$ & $51-75 \%$ \\
$26-50 \%$ & $76-100 \%$ \\
\hline
\end{tabular}

2. Does your facility have a written policy about homosexual workers? yes no no_ don't know

3. Do you think there are homosexual workers at your facility? yes _ no n_ don't know

4. Are any workers at your facility openly homosexual? yes no don't know

5. What effect do you believe homosexual workers have on patients?

bad good no effect don't know

6. In your opinion, what percentage of patients at your facility are consciously homosexual?

$\begin{array}{r}0-25 \% \\ -26-50 \% \\ \hline\end{array}$

7. Does your facility have a written policy homosexual patients? yes If so, in your opinion, is it: too permissive adequate too restrictive

8. How would you determine if a patient is homosexual? (rank) case record sexual incidents patient tells you other, explain
$51-75 \%$ $65-100 \%$ 
10. Homosexual patients are usually (lower, middle, upper) economic class.

11. Compared to other patients, homosexual patients are:

Check One

Intelligent
Clean
Disruptive
Paranoid
Active
Compulsive
Mature
Anxious
Hallucinatory
Vocal
Sensitive
Hostile
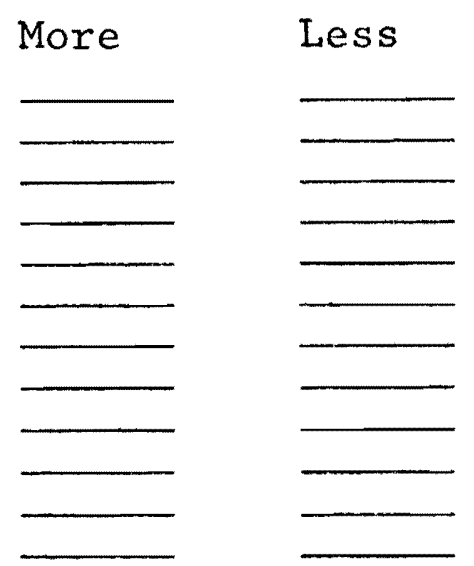

Same

12. In your opinion, do homosexual patients have special. problems that other patients don't have?

Yes No

If so, what?

13. Should your facility have special treatment programs for homosexual patients? yes no

If no, why not?

If so, what kind of programs?

14. In your opinion, can a heterosexual therapist effectively treat a homosexual patient? yes no

15. In your opinion, can a homosexual therapist effectively treat a heterosexual patient? yes no 
Part Three: Personal Attitudes

Please rate your opinion about the following statements.

$\begin{array}{llll}\text { strongly } & \begin{array}{l}\text { tend } \\ \text { to }\end{array} & \begin{array}{l}\text { tend } \\ \text { to }\end{array} & \text { strongly } \\ \text { agree } & \text { agree } & \text { agree } & \text { disagree disagree } \\ \text { disagree }\end{array}$

1. People shouldn't be labeled by their sexuality.

6

5

4

3

2

1

2. I would like to have a homos exual experience

6 5
4

3

2

1

3. It dosen't matter what people do in bed.

4

3

1

4. Homosexuals are afraid of the opposite sex.

5. Homosexuals are narcissistic 6

5

4

3

6. Homosexuality

is healther

than

heterosezuality 6

5

4

3

2

1

7. Everyone. should be bi-sexus?.

8. Homosexuality

is the

product of

broken homes

6

5

4

3

2

1

9. Everyone is basicaliy homosexual

4

3

2

1

10. I hope my children become homosexual 


\begin{tabular}{|c|c|c|c|c|c|}
\hline t? & & $\begin{array}{l}\text { tend } \\
\text { to }\end{array}$ & $\begin{array}{l}\text { tend } \\
\text { to }\end{array}$ & & strongly \\
\hline gre & agree & agree & disagree & disagree & disagree \\
\hline
\end{tabular}

11. Homos exuals should be put in jail

6

54

3

2

1

12. Homosexuals are no problem as long as they don' $t$ flaunt it.

6

5

4

3

2

1

13. Homosexuals were strong enough to resist heterosexual social pressure when they were growing up.

6

54

3

1

14. Homosexuals

hate the opposite sex

6

5

4

3

1

15. Homosexuality is a sickness not a crime

6

5

4

3

1

16. Homosexuals

are more attractive than heterosexuals

3

17. Homosexualjty is unnatural

18. Homosexuals can change with help

19. I avoid homosexuals whenever possible

20. Homosexuals have a lot to teach heterosexuais. 


\begin{tabular}{llll} 
& tend & tend & \\
strongly & to & to & strongly \\
agree & agree & agree & disagree disagree \\
\hline
\end{tabular}

21. Homosexuality

is not immoral,

but can lead

to immoral

actions.

6

5

4

3

2

1

22. Homosexuals

should be

kept away

from children

6

5

4

3

2

1

23. Homosexual

relationships

are more equal

than hetero-

sexual relation-

ships.

6

5

4

3

2

1

24. Homosexuality

is all right

for some, but

not for me.

6

5

4

3

2

1

25. A significant

number of

child-molesters

are homos exual. 6

5

4

3

2

1

26. Heterosexuals

fear members of

the same sex.

6

5

4

3

2

1

Thank you for your cooperation. 
APPEINDIX B

\section{EXPLANATION SHEET}

This questionnaire is part of a research paper for a masters degree in social work at Portland State University. It is being given to Psychiatric nurses, and Aides at Oregon's three state mental hospitals.

The findings will also be made available to the Task Force on Sexual Preference if useful. This Task Force was set up by Governor Straub, to be administered through the Department of Human Resources, to provide information on the status of homosexuals as related to the functioning of state agencies.

Participation is on a completely voluntary basis. No information identifying your hospital, or your identity, is requested. Do not sign your name. Please refrain frorn discussing the contents of this questionnaire until all responses have been returned. Please answer the questions as completely and honestly as possible. Promptness in completing and mailing this questionnaire will be greatly appreciated.

Thank you very much for your cooperation. 